\title{
Geobody architecture, genesis and petrophysical characteristics of the Budakalász travertines, Buda Hills (Hungary)
}

\author{
H. Claes a, *, M. Degros a , J. Soete ${ }^{\text {a }, ~ S . ~ C l a e s ~}{ }^{\text {a }}$, S. Kele ${ }^{\mathrm{b}}$, A. Mindszenty ${ }^{\mathrm{c}}$, Á. Török a, c, \\ H. El Desouky ${ }^{\mathrm{d}}$, F. Vanhaecke ${ }^{\mathrm{e}}$, R. Swennen ${ }^{\mathrm{a}, * *}$ \\ ${ }^{a}$ Geology, Earth and Environmental Sciences, KU Leuven, Celestijnenlaan 200E, 3001 Heverlee, Belgium \\ ${ }^{\mathrm{b}}$ Institute for Geological and Geochemical Research, Hungarian Academy of Sciences, Hungary \\ ${ }^{\mathrm{c}}$ Institute of Geography and Earth Sciences, Dept. of Physical and Applied Geology, Eötvös L. University, Pázmány P. Sétány 1/c, H-1117 Budapest, Hungary \\ ${ }^{\mathrm{d}}$ Geology Department, Faculty of Science, Menoufia University, Shebin El-Kom, Menoufia 32512, Egypt \\ e Department of Analytical Chemistry, Ghent University, Krijgslaan 281-S12, Ghent B-9000, Belgium
}

\section{A R T I C L E I N F O}

\section{Article history:}

Available online $\mathrm{xxx}$

\section{Keywords:}

Lithofacies geobody

Travertine

Porosity-permeability

Isotope geochemistry

Lobe

\begin{abstract}
A B S T R A C T
Subsurface Pre-salt Lower Cretaceous reservoir systems encountered offshore Brazil and Angola that consist of porous continental carbonates are difficult to access because of the limited core material that is under concession. Therefore, it is important to study comparable continental carbonate analogues, such as travertines and lacustrine carbonates, that potentially possess similar porosity and permeability characteristics. The Budakalász Pleistocene travertines (Buda Hills, Hungary) have been studied from a sedimentological, geochemical and reservoir properties point of view in order to understand their formation, petrophysical properties and 3D reservoir architecture.

The three-dimensional geobody architecture of the Budakalász travertines illustrates the potential complexity of kilometre scale continental carbonate systems. Heterogeneous low angle sloping travertine lobes consisting of terrace slope, smooth slope and reed facies, are covered by a lime mudstone dominated, gastropod- and charophyte-rich marsh-pool facies. The observed facies represent a change from a subaerial travertine to a palustrine to lacustrine system, reflecting the ceasing of the system due to tectonic uplift. The dominant paleo-flow direction of the sloping lobes was towards the Danube depression, with several subordinate flow systems identified.

The $\mathrm{Sr}-\mathrm{C}-\mathrm{O}$ isotope geochemical signatures reflect travertine precipitation at ambient to superambient temperatures from meteoric derived fluids with a mixed $\mathrm{CO}_{2}$ origin of the marine carbonate substrate rocks, a potential atmospheric and a soil-derived component. Although the uniform signatures of the stable oxygen and carbon isotopes, in addition to petrographic observations suggest partial diagenetic isotopic resetting, the primary isotope trends seem to have been preserved.

A reservoir-oriented facies evaluation in the three-dimensional geobody frame of the Budakalász carbonates based on porosity and permeability core plug analyses reveals their heterogeneous nature. Terrace, smooth slope and marsh-pool facies have considerable porosities of $5-15 \%$, while the porosity of the reed facies may reach up to $27 \%$. Permeability of all facies is strongly anisotropic, mainly controlled by a better connectivity along layer-parallel primary pores.

The reconstruction of the 3D geobody architecture of the Budakalász lobe complex coupled to its geochemical and petrophysical properties provides a unique dataset that contributes in understanding fossil travertine systems.
\end{abstract}

๑) 2016 Elsevier Ltd and INQUA. All rights reserved.

\section{Introduction}

The interest in continental carbonates, such as travertines and lacustrine carbonates, increased over the last years, particularly

\footnotetext{
* Corresponding author.

** Corresponding author.

E-mail addresses: hannes.claes@kuleuven.be (H. Claes), rudy.swennen@ kuleuven.be (R. Swennen).
}

since recent discoveries of oil fields in similar lithologies, for example offshore Brazil (Beasley et al., 2010). Benchmarking continental carbonate research was already carried out before these discoveries. There is an important discussion in literature on the nomenclature of spring-related carbonates, like the distinction between travertine and tufa (e.g. Pentecost, 2005; Capezzuoli et al., 2014; Della Porta, 2015; Claes et al., 2015a). In this study, travertine is considered sensu lato, i.e. without separation from tufa (sensu 
Pentecost, 2005), as a continental carbonate that formed by precipitation from carbonate-supersaturated water caused primarily by the transfer of $\mathrm{CO}_{2}$ (Pentecost, 2005). Further distinction is possible based on the stable isotope signatures (see e.g. Pentecost, 2005; Crossey et al., 2006; Teboul et al., 2016).

Some key review documentation on the sedimentology of travertines was assembled by Chafetz and Folk (1984), Pedley (1990), Guo and Riding (1994, 1998), Chafetz and Guidry (1999), Ford and Pedley (1996), Pentecost (2005), Gandin and Capezzuoli (2008) and more recently by Pedley and Rogerson (2010), Fouke (2011), Brasier (2011), Capezzuoli et al. (2014) and Della Porta (2015). One of the remaining key challenges in these studies is the extrapolation from recent settings, where variations in deposits can be seen from vent to distal positions (e.g. Fouke, 2011), to fossil deposits that reflect both spatial and temporal variation of the depositional system. In the latter, it is often difficult to infer seemingly straightforward characteristics, like the paleomorphology, vent location and flow direction. However, by studying outcrops from active quarries, in function of the orientation of the quarry walls, a $2 \mathrm{D}$ to pseudo-3D reconstruction can be worked out. Although many studies already included lithofacies-lithotype description and interpretation (e.g. Guo and Riding, 1998; Özkul et al., 2002; Gandin and Capezzuoli, 2014), a reconstruction of their 3D geobody architecture was rarely included. Some recent studies gave insight in the 3D architecture of these systems (e.g. Gradzinski et al., 2014; Claes et al., 2015a; Croci et al., 2016; Huerta et al., 2016), but only few sedimentological models were accompanied with petrophysical data. From a reservoir point of view, both to the geobody architecture and the petrophysical heterogeneities within the bodies should be understood. Although the porous nature is one of the key characteristics of these deposits, a detailed investigation of porosity, permeability and other petrophysical properties has only become available recently (Ronchi and Cruciani, 2015; Soete et al., 2015; Lebatard et al., 2014; Claes et al., 2015b; De Boever et al., 2016) and should be extended.

The aim of this research is to provide an integration between the geobody architecture of the Pleistocene Budakalász travertines, quarried in the Buda Hills (Hungary) and their genesis and porosity-permeability properties.

\section{Geological setting and travertine occurrence}

The travertine quarries near the village of Budakalász are situated in the Buda Hills, which are part of the Transdanubian Range (TR) in the central part of the Pannonian Basin. In the Buda Hills, the TR is mainly composed of Mesozoic carbonates that are covered by Cenozoic siliciclastic and carbonate sequences (Trunkó, 1996; Haas et al., 2001). The high topographic differences between meteoric recharge, e.g. Buda Hills and adjoining sectors of the TR, and discharge areas, i.e. the incised river terraces of the River Danube, resulted in strong hydraulic gradients. Gravity is the principal driving force for subsurface water circulation in the area (e.g. Eróss et al., 2012; Mádl-Szőnyi and Tóth, 2015) likely channelized along paleokarst horizons which developed in the carbonate rock succession (Nádor, 1993; Györi et al., 2011). The higher than average geothermal gradient of the Pannonian Basin (e.g. Árpási et al., 2000; Lenkey et al., 2002), associated with its extensional setting is the reason for the abundant thermal waters of the Buda Hills. Infiltrated and heated meteoric water can mix with karstic water and/ or basinal brines, resulting in corrosive fluids that enhance carbonate dissolution. Surfacing of $\mathrm{CO}_{2}$ - and $\mathrm{H}_{2} \mathrm{~S}$-rich, thermal fluids resulted in the degassing and associated precipitation of travertines (Nádor, 1993; Goldscheider et al., 2010; Sierralta et al., 2010) and associated mineralizations. Some authors suggested that the first phase of thermal water activity in the region might have initiated as early as the Late Oligocene - Early Miocene (Báldi and Nagymarosy, 1976; Nádor, 1991), as a result of the influence of the nearby neo-volcanic activity of the Visegrád Mountains (Nádor, 1993), which is part of the regional calc-alkaline volcanism of the Inner Carpathian Volcanic Chain (Karátson et al., 2006, 2007). Other authors (e.g. Poros et al., 2012), argued that the thermal event had no direct connection to the volcanic activity. They believe that the present fluid circulation system was established only in the Late Miocene times, well after the decline of volcanism and was related to the elevated heat flux of the extensional basin. From the Late Middle Eocene throughout the Oligocene and up to the Early Miocene, the Buda Hills were subjected to a stress field resulting in large-scale strike-slip movements (Fodor et al., 1994; Poros et al., 2012). By latest Miocene times, the Buda Hills became sub-aerially exposed and intense erosion of the Palaeogene sequence started. Simultaneously, due to NW-SE trending normal faulting, horst and graben structures developed (Földvári et al., 1988; Poros et al., 2012). The latter are very typical for the Buda Hills (Fig. 1). The gradual uplift of the Buda Hills, starting from the Late Miocene, caused erosion of the clayey cover and exposure and karstification of the TriassicEocene-Early Miocene carbonate rocks in the area of the highest peaks (Nádor, 1993; Goldscheider et al., 2010). Meteoric waters infiltrated through the exposed carbonate sequences of the Transdanubian Range, where they got heated and saturated with carbonates before they reascended in the Buda Hills as thermal waters. During upward migration, they may have mixed with locally infiltrating cold karstic waters and brines ascending from the direction of the Pannonian Basin (Poros et al., 2012). When these thermal waters surfaced, travertines were precipitated (Scheuer and Schweitzer, 1988; Nádor, 1993). In Pleistocene times, travertines formed at the margins of the uplifting Buda Hills, mainly along NW-SE trending normal faults (Fig. 1). Accelerating uplift, changes in the water supply and incision of the Danube River caused the formation of at least seven gravel terraces (Wein, 1977; Kovács and Müller, 1980). Travertines as well as alluvial deposits formed on these terraces. Some of these travertines have been studied with regard to their age, fauna content and their implications for the environmental changes in Hungary (e.g. Sierralta et al., 2010; Pazonyi et al., 2014). In accordance with the incision of the Danube River (i.e. base level lowering) the hydrological system was subject to continuous reorganization. Therefore, the most recent travertine deposits are situated topographically lower than their Pleistocene equivalents (Pécsi, 1973; Scheuer and Schweitzer, 1988; Kele et al., 2003; Kele, 2009). The Budakalász travertines are one of these Pleistocene deposits (Fig. 1), covering the slopes and terrace steps and the stratigraphically underlying Lower Oligocene Hárshegy Sandstone and Kiscell Clay Formations (Scheuer and Schweitzer, 1988). The travertines are covered by a few meters of loess, itself overlain by a thin $(10-30 \mathrm{~cm})$ humus-rich soil layer (Kele et al., 2003). The Budakalász travertines have been dated using the uranium-thorium method at the bottom and the top of the section, resulting in ages of respectively 57097 and $27434 \mathrm{ka}$ (Kele, 2009). Based on these data a minimum precipitation rate of $0.07 \mathrm{~mm} /$ year can be deduced (Kele, 2009).

\section{Methodology}

\subsection{Fieldwork and high resolution photography}

Field mapping of the more than 1000 by 300 m sized Budakalász total travertine body (Fig. 1; Fig. 2) was carried out in July 2012 and January 2016. These travertines have been quarried over a section of $\sim 550 \mathrm{~m}$ (Fig. 2). Detailed characterisation focused on the central $130 \mathrm{~m}$ of the quarry, since here, due to recent excavation of travertine blocks, exposure conditions were optimal for investigation 


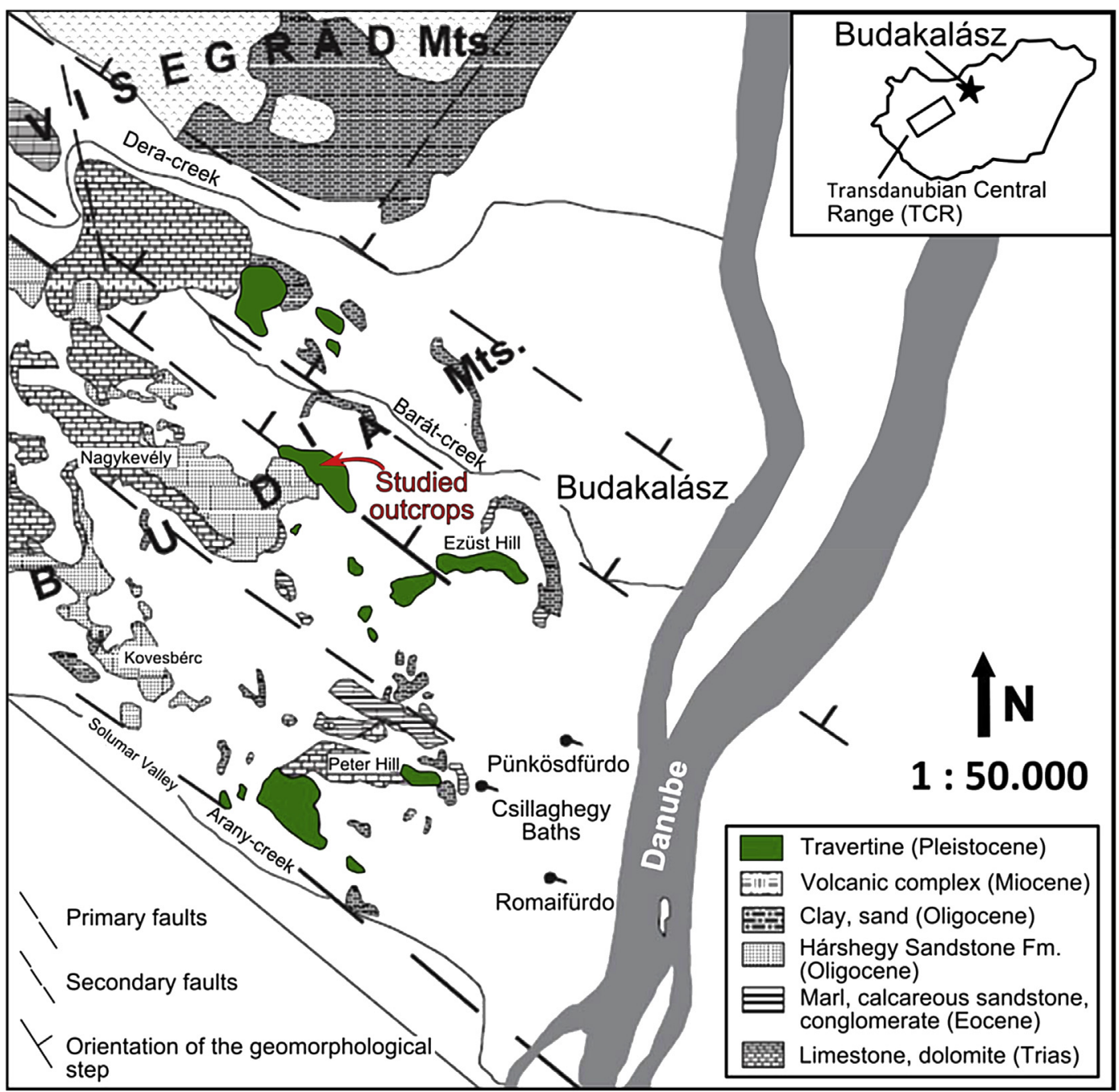

Fig. 1. Geological sketch map showing the location of the Budakalász and adjacent travertine outcrops (modified from Kele et al., 2003; after Szlabóczky, 1982).

(Fig. 2). The maximal thickness based on exposure and borehole information (Scheuer et al., 1987) is $20 \mathrm{~m}$, whereas the maximum exposed thickness is $17.8 \mathrm{~m}$.

High resolution photographs were taken over the entire quarry along the different excavation levels. These photographs, on which the sedimentary features and lithofacies characteristics were drawn (further called as line-drawings, e.g. Fig. 3), served as a basis for the 3D reconstruction of the quarry in SketchUp and with photogrammetry. The combination of the 3D model and the detailed line-drawings allowed assessing vertical and lateral variations of the different lithologies.

Horizontal and vertical core sampling was performed along the accessible quarry walls. By drilling, $10 \mathrm{~cm}$ diameter and $20-30 \mathrm{~cm}$ long full cores ( 18 vertical and 9 horizontal cores) were taken. In addition, 1.5 and 1 inch (respectively 3.81 and $2.54 \mathrm{~cm}$ diameter) small diameter cores of $5-8 \mathrm{~cm}$ in length, further referred to as core plugs, were taken ( 6 vertical and 8 horizontal). The drilling was carried out with a modified handheld STIHL petrol driven engine with diamond core drill bit.

\subsection{Petrography}

Samples were impregnated twice with a fluorescent dye before thin-section preparation. The fluorescent resin improves the visualization of (micro)porosity when using incident fluorescent light microscopy. Detailed petrographic characterization was conducted on an Olympus BX60 and Leica DM LP Parallel and Crossed Polar Optical and Fluorescence microscope (PPM, CPM \& FM respectively). A Nikon OptiPhot with in-house modified Technosyn Model 8200 Mark II stage was used for Cold Cathodoluminescence (CCL) observations. Usage of a JEOL JSM-6400 Scanning Electron Microscope (SEM) allowed observations in pseudo-3D at high magnifications $(50,000 \times)$. With respect to the description of components, Pentecost's (2005) terminology was used. Here, the carbonate components are divided into micrite (0-5 $\mu \mathrm{m}$ in size), microspar (5-35 $\mu \mathrm{m}$ in size) and macrospar (>35 $\mu \mathrm{m}$ in size).

\subsection{Carbon and oxygen isotopes}

Stable carbon and oxygen isotope measurements were carried out on 33 samples at the 'Friedrich-Alexander-Universität' (Erlangen-Nürnberg, Germany). The samples were selected based on their representativity with regard to facies and to their relative position in the quarry. In most cases, both rock framework and pore reducing crystalline cement phases were separately sampled using a Dremel micro-drill. Carbonate powders reacted with $100 \%$ phosphoric acid at $70{ }^{\circ} \mathrm{C}$ using a Gasbench II connected to a 

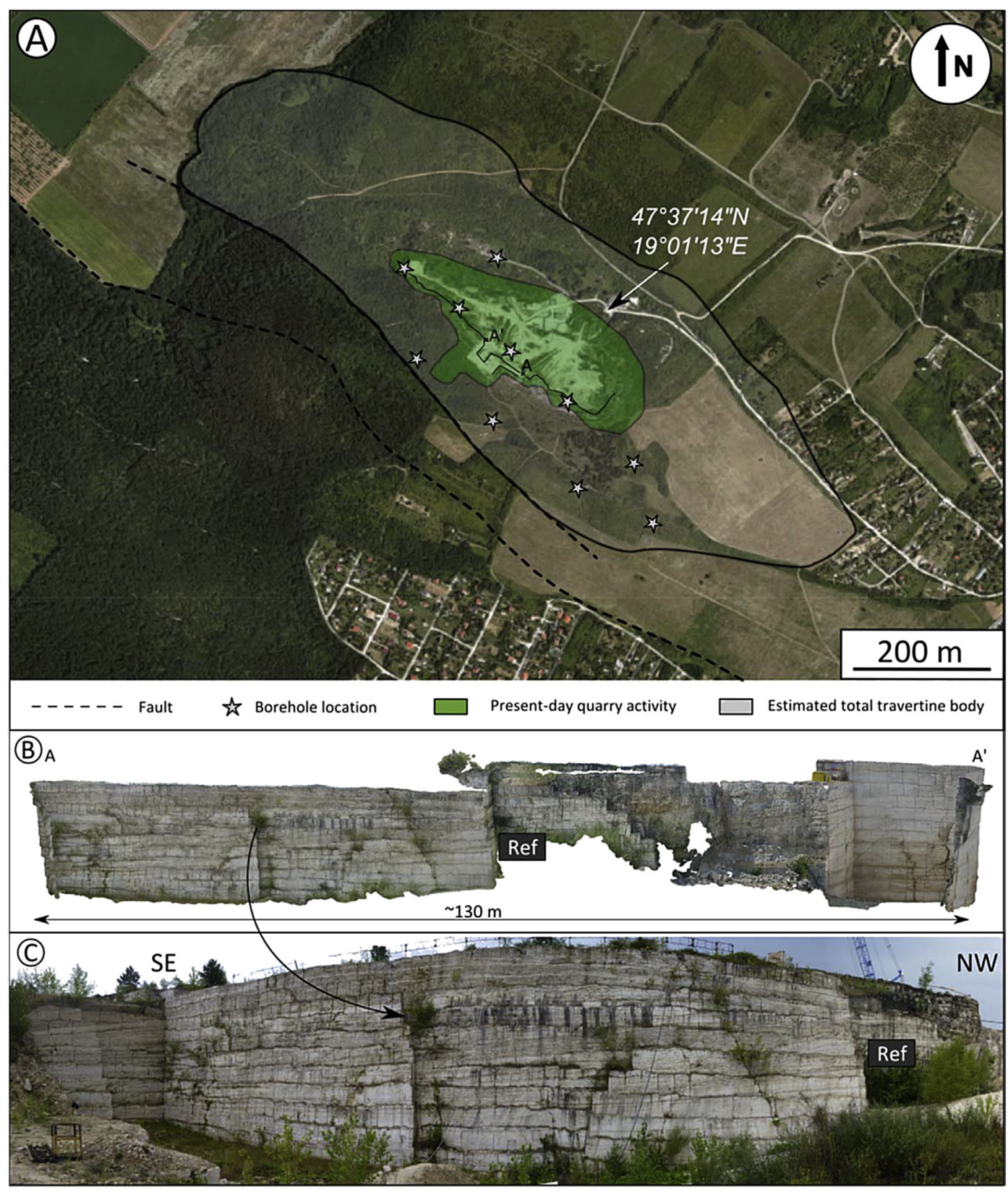

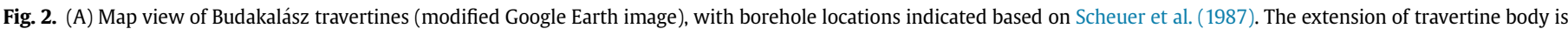

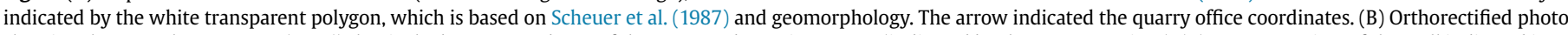

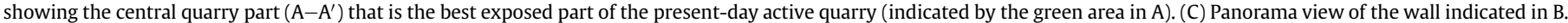
(For interpretation of the references to colour in this figure legend, the reader is referred to the web version of this article.)

ThermoFinnigan Five Plus mass spectrometer. All values are reported in per mil (\%o), relative to the Vienna Pee Dee Belemnite (VPDB) by assigning a $\delta^{13} \mathrm{C}$ value of $+1.95 \%$ and a $\delta^{18} \mathrm{O}$ value of $-2.20 \%$ to the NBS19 standard. Reproducibility was attained by replicate analysis of laboratory standards and is better than $0.05 \%$ for both carbon and oxygen isotope ratios.

\section{4. $R b-S r$ isotopes}

The $\mathrm{Rb}$ and $\mathrm{Sr}$ contents and the ${ }^{87} \mathrm{Rb} /{ }^{86} \mathrm{Sr}$ and ${ }^{87} \mathrm{Sr} /{ }^{86} \mathrm{Sr}$ were determined for 8 representative samples at the Department of Analytical Chemistry, Ghent University (Belgium). The carbonate powders were drilled using a Dremel dental microdrill from the different carbonate phases of interest (rock framework and cements). The sample powders were weighed in a screw-capped Savillex ${ }^{\circledR}$ PFA vial and dissolved in $6 \mathrm{M} \mathrm{HCl}$ on a hotplate. The digests were subsequently evaporated to dryness and redissolved in $7 \mathrm{M} \mathrm{HNO}_{3}$. The $\mathrm{Rb}$ and $\mathrm{Sr}$ concentrations were determined using a Thermo Scientific XSeries 2 quadrupole-based ICP-MS instrument using external calibration combined with $\mathrm{Y}$ as an internal standard (Vanhaecke et al., 1992). The ${ }^{87} \mathrm{Rb} /{ }^{86} \mathrm{Sr}$ ratios were calculated following the procedures described by Vanhaecke et al. (1999).

$\mathrm{Sr}$ was subsequently isolated from the sample using a $\mathrm{Sr}$ selective resin ( $\mathrm{Sr} \mathrm{spec}^{\mathrm{TM}}$ ), following the extraction chromatography procedure described in detail by De Muynck et al. (2009). Sr isotopic measurements were performed using a Thermo Scientific Neptune MC-ICP-MS instrument. The intensities obtained for ${ }^{83} \mathrm{Kr}$ and ${ }^{85} \mathrm{Rb}$ were used to correct for the $\mathrm{Kr}$ and $\mathrm{Rb}$ interferences 

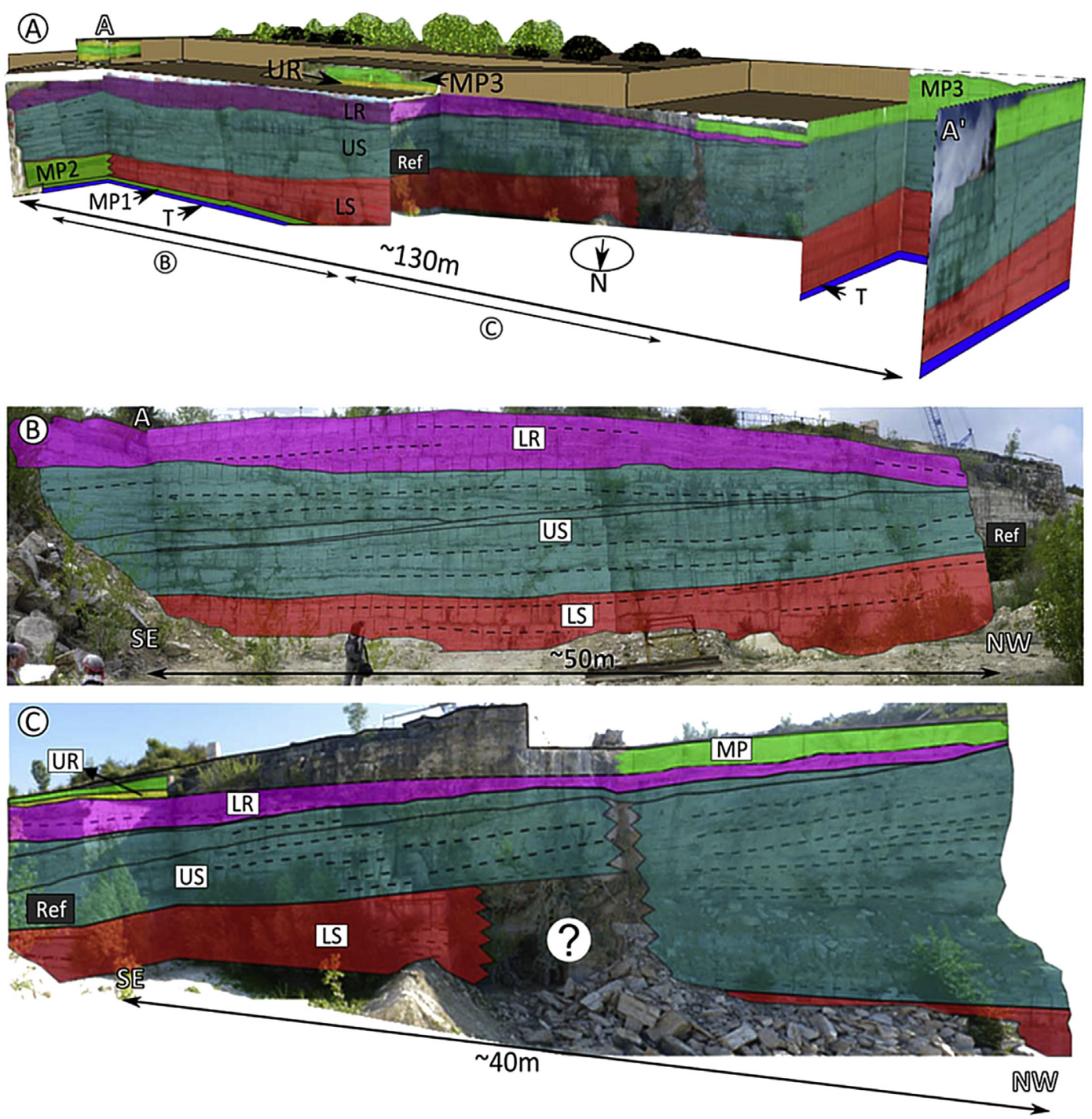

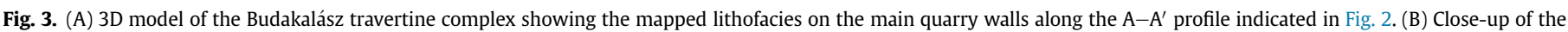
southeastern section of 3A. Note the two wedge-shaped bodies within the upper smooth slope facies (US). Lower facies not visible from this angle. (C) Close-up of the middle section of 3A. Note the wedging out of the upper part of the upper smooth slope facies (US) and the lower reed facies (LR). The upper layers of the low angle smooth slope facies (LS) gradually change into the upper smooth slope facies (US) to the northwest (see question mark). Dashed lines denote the bedding. $T=$ Terrace slope facies, UR $=$ Upper reed facies, MP = Marsh-pool facies (3 different occurrences).

(Balcaen et al., 2005). The Sr isotope ratios were normalized to the accepted ratio of 0.1194 (Steiger and Jager, 1977). Blank Sr signals were negligible compared to the $\mathrm{Sr}$ intensities encountered for samples and standards. Within the external precision, repeated analyses of the NIST SRM $987 \mathrm{SrCO}_{3}$ over the duration of this study yielded an average ${ }^{87} \mathrm{Sr} /{ }^{86} \mathrm{Sr}$ ratio of $0.710299 \pm 0.000022(\mathrm{n}=33)$, which is in good agreement with the accepted ${ }^{87} \mathrm{Sr} /{ }^{86} \mathrm{Sr}$ ratio of 0.710248 for this material (Thirlwall, 1991).

\subsection{Porosity and permeability analyses}

The effective porosity of 39 core plugs ( 1.5 inch, 25 vertical and 14 horizontal, most of which were drilled out of the cores) was measured by means of helium expansion porosimetry. Gas permeability, in this case with nitrogen gas $\left(\mathrm{N}_{2}\right)$, was measured in a steady state permeameter. In addition a selection of 11 one inch core plugs ( 5 vertical and 6 horizontal) were analysed. Both analyses were carried out by PanTerra Geoconsultants B.V. (Leiderdorp, The Netherlands).

\subsection{Computed Tomography analyses}

Medical Computed Tomography (CT) was used to make a 3D visualization and quantification of the macropore networks, encountered in the different lithological facies. All the full core samples were scanned using a Siemens Somatom Definition Flash at the University Hospital Gasthuisberg (KU Leuven, Belgium). Single energy scans (at $120 \mathrm{kV}$ ) allowed obtaining scan resolutions of $0.6 \times 0.6 \times 0.5 \mathrm{~mm}$. The segmentation of reconstructed images $(512 \times 512$ pixels $)$ and subsequent total porosity calculations were performing in Matlab. Micro-Computer Tomography $(\mu \mathrm{CT})$ scans were carried out on a representative selection of six one inch core plugs. The samples were scanned with a SkyScan 1172 desktop X-ray microtomography instrument at approximately $100 \mathrm{kV}$ and $100 \mu \mathrm{A}$. The voxel resolution for the scans is $28 \times 28 \times 28 \mu \mathrm{m}^{3}$. Based on the projection data, a three dimensional reconstruction is made and slices are exported. The slices were segmented and analysed in Matlab and Avizo Fire (v.7) software. The limited diameter of the core plugs raises the question of the representativity of some of the 
samples knowing that the pores in these samples may have a diameter of several millimetres. However, it was mathematically proven based on CT-analysis, that the samples fulfil the "Representative Elementary Volume" criterion for pores with sizes below the core plug scale (Claes et al., 2015b).

\section{Results}

\subsection{Lithofacies}

The lithofacies nomenclature in this manuscript is conformable with the earlier classifications. Four main travertine lithofacies are distinguished and mapped, i.e. observed from bottom to top (Fig. 3): the terrace slope facies (Guo and Riding, 1998), the smooth slope facies (Guo and Riding, 1998), the reed facies (Claes et al., 2015a) and the marsh-pool facies (Guo and Riding, 1998). They are described according to the observations in the Budakalász quarry in Table 1. The lithotype terminology is based on Gandin and Capezzuoli (2014) and Ford and Pedley (1996). Figs. 4-7 illustrate the typical characteristics of the distinguished lithofacies.

In the central part of the quarry, the strata are dipping by a few degrees to the SE. In the older parts of the quarry, paleoslopes were deduced but detailed facies mapping and characterisation was not always straightforward due to weathering and biogenic activity coverage, e.g. lichen growth. In the north-western part of the quarry, slopes have a main north to north-western dip direction, while in the south-eastern part of the quarry layers were dipping east to southeast.

The lateral and vertical transitions and occurrences of the facies are illustrated in Fig. 3. In the bottom part of the central part of the quarry, low angle dipping (always $<10^{\circ}$ ) terrace slope travertines (Fig. 4), of maximally $1 \mathrm{~m}$ thick exposure, vertically change into a $\sim 1 \mathrm{~m}$ thick first marsh-pool facies occurrence (Fig. 7). They are cut off with an erosional surface. The previous facies are covered by, firstly, low angle $\left(3-5^{\circ}\right)$ smooth sloping, and subsequently, higher angle $\left(4-10^{\circ}\right)$ smooth sloping travertines (Fig. 5) of up to $13 \mathrm{~m}$ in total, that laterally change into a second marsh-pool facies occurrence (Fig. 3). The latter facies, vertically transition into an up to $5 \mathrm{~m}$ thick reed facies (Fig. 6) and finally into a third occurrence of the marsh-pool facies (Fig. 7), of about $4 \mathrm{~m}$ thick.

The main lithotypes are spongy microbial bindstones, dendrite crusts, phytoherm and phytoclastic travertines and lime mudstones. Their associations for the different facies are illustrated in Table 1, together with the lithotype related fabrics and pore types. With exception of the lime mudstones of the marsh-pool facies, the lithotypes consist of sparite-dominated fabrics. In the latter, micrite patches, peloids and clumps are often grouped in wavy to horizontal laminae, which are embedded in (micro-) sparites.

\subsection{Diagenesis}

The petrographic evaluation of the Budakalász samples shows that post-depositional processes significantly altered the fabrics. The main processes involved are cementation, dissolution, decay, micritisation and recrystallisation.

The whole process of precipitation of travertines could be considered as cementation between organic fabrics (see discussion in Pentecost, 2005). The focus here, however, lies on the pore reducing cementation. Most of the pores of the Budakalász travertines are cement reduced or entirely filled by subhedral equant to columnar spars (e.g. Figs. 4E and 5D-G). Different generations of cementation can be recognised for example by the microlamination inside the cements (e.g. Fig. 5D). Often the crystal edges of the spars are rounded indicating some minor dissolution (e.g. Fig. 5D). Dissolution is more pronounced for ostracod and gastropod moulds (e.g. Fig. 7E) and where (micro-)structures are partly dissolved (e.g. Fig. 5G). Examination by fluorescence microscopy reveals the generation specific isopachous cement dissolution as shown in Fig. 8A and B. Plant and charophyte mouldic porosity indicating organic decay is widely observed (e.g. Figs. 6 and 7D), mostly in the reed facies but also in the other facies.

Fabrics of interest for the evaluation of micritisation or recrystallisation (see discussion) are micrite patches in cloudy sparite crystals (Fig. 8C), for which laterally in the same sample clean sparite crystals are found. Microporosity is observed in association with the micrite (Fig. 8C-E). A second fabric of interest is observed in the structure edges in the form of micrite envelopes (e.g. Fig. $4 \mathrm{E}-\mathrm{G}$ and $5 \mathrm{H})$. Furthermore, the uniform undulose extinction from sparmicritic dendrite crystals to surrounding spars (Fig. $8 \mathrm{C}-\mathrm{G}$ ) and the undulose extinction over several crystals (Fig. $8 \mathrm{H}-\mathrm{I}$ ) are observed.

\subsection{Stable $\mathrm{O}-\mathrm{C}$ and radiogenic $\mathrm{Sr}$ isotope geochemistry}

The $\delta^{18} \mathrm{O}$ values range between -13 and $-10.4 \%$ V-PDB (mean $=-11.9 \%$ o $\mathrm{V}$-PDB) for the rock framework carbonates and between -13 and $-10.5 \%$ V-PDB (mean $=-11.4 \%$ V-PDB) for the cement carbonate samples. The $\delta^{13} \mathrm{C}$ values range between 0.2 and $2.5 \% \mathrm{~V}$-PDB (mean $=1.7 \% \mathrm{~V}-\mathrm{PDB}$ ) for the rock framework and between -0.6 and $2.4 \% \mathrm{~V}$-PDB (mean $=1 \%$ V-PDB) for the cement samples (Fig. 9). The mean values of $\delta^{18} \mathrm{O}$ and $\delta^{13} \mathrm{C}$ for the cement phases thus exhibit respectively a positive $(0.5 \%)$ and negative $(-0.7 \% 0)$ shift relative to the rock framework phases. This general shift, however, is a mixture of different cementation effects. In Fig. 9, the cement and rock framework samples are plotted according to their facies. A general depletion of the $\delta^{13} \mathrm{C}$ values ( 0.5 to $>1 \%$ ) and enrichment of the $\delta^{18} \mathrm{O}$ values $(0.2$ to $>1 \%$ ) are observed for the cement samples in comparison to the rock framework samples. Only in the lower smooth slope facies an opposite trend is observed, with an increase of up to $1.5 \%$ for $\delta^{13} \mathrm{C}$ and a decrease by $>1 \%$ for the $\delta^{18} \mathrm{O}$ values. For the terrace slope facies, the $\delta^{18} \mathrm{O}$ signature of the cement is enriched by almost $1 \%$, and the $\delta^{13} \mathrm{C}$ is constant relative to the rock framework signatures. Based on their general signatures, the terrace slope facies and marsh-pool facies samples can be clearly distinguished from the other facies (Fig. 9). The terrace slope carbonates show an enriched $\delta^{13} \mathrm{C}$ and a similar $\delta^{18} \mathrm{O}$ signature compared to the signatures of the other facies. The marsh-pool samples show an enrichment in both $\delta^{18} \mathrm{O}$ and $\delta^{13} \mathrm{C}$ signatures relative to the signatures of the other facies. In general, the samples from this study are less enriched in $\delta^{13} \mathrm{C}$ and more depleted in $\delta^{18} \mathrm{O}$ compared to the previous data of the same quarry (Fig. 9; Földvári et al., 2003; Kele et al., 2003).

The ${ }^{87} \mathrm{Sr} /{ }^{86} \mathrm{Sr}$ ratios of the travertine samples display a uniform signature that varies between 0.70841 and 0.70844 (mean =0.070842; Fig. 10) and low ${ }^{87} \mathrm{Rb} /{ }^{86} \mathrm{Sr}$ ratios (less than 0.004 ), with no correlation between the ${ }^{87} \mathrm{Rb} /{ }^{86} \mathrm{Sr}$ and ${ }^{87} \mathrm{Sr} /{ }^{86} \mathrm{Sr}$ ratios. As the concentration of $\mathrm{Rb}$ in Ca-carbonates is very low, age correction is negligible. The analysed samples show variable $\mathrm{Sr}$ elemental concentrations (339-735 ppm) with the highest values reported from the upper smooth slope facies (Fig. 10).

\subsection{Porosity-permeability and micro-Computer Tomography $(\mu \mathrm{CT})$}

Porosity and permeability results of the analysed core plugs (examples shown in Fig. 11) are shown in Fig. 12. The porosity values range between 6.8 and $27 \%$ (mean $=14 \%$ ) for the vertically oriented core plugs, and between 5.2 and $26.2 \%$ (mean $=13.4 \%$ ) for the horizontally oriented core plugs. Empirical Klinkenberg permeability values (further on denoted as permeability values) range from 0.03 till $6510 \mathrm{mD}$ (mean $=521 \mathrm{mD}$ ) in vertical core plugs and from 0.09 till $25,900 \mathrm{mD}$ (mean $=3682 \mathrm{mD}$ ) in 


\begin{tabular}{|c|c|c|c|c|c|c|c|}
\hline & 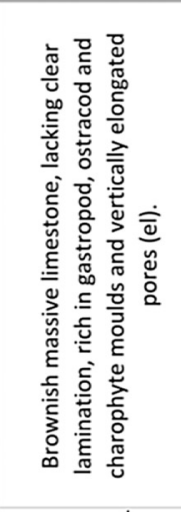 & 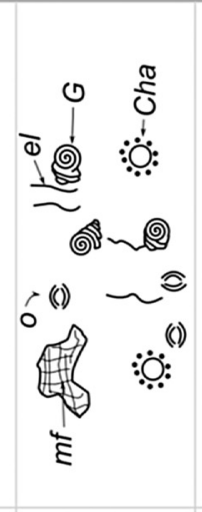 & 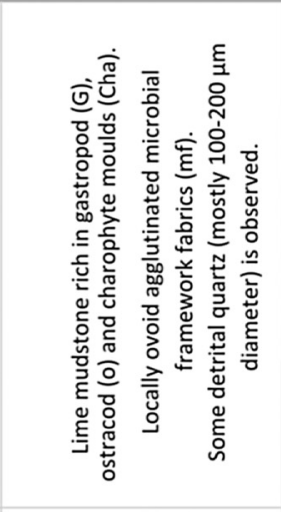 & 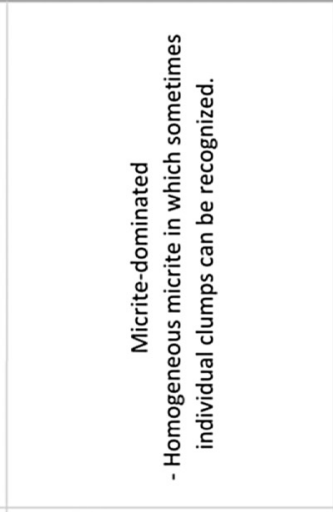 & 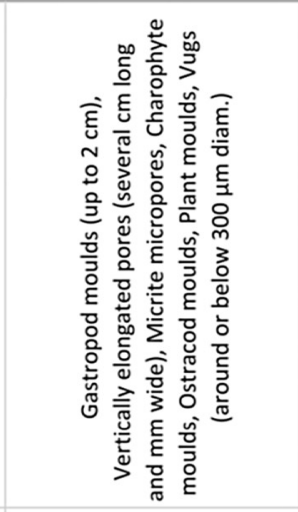 & 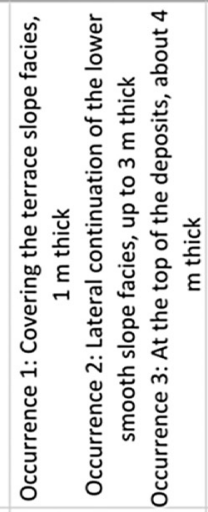 & \\
\hline 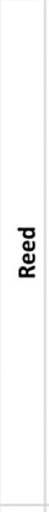 & 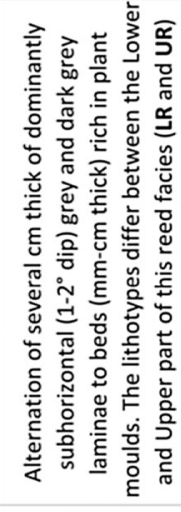 & की & 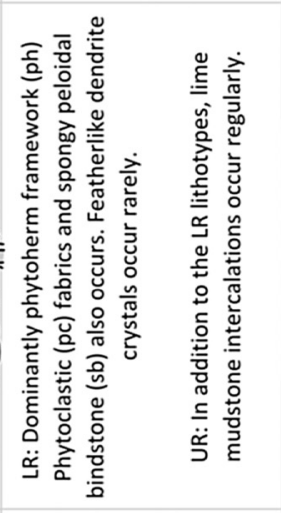 & 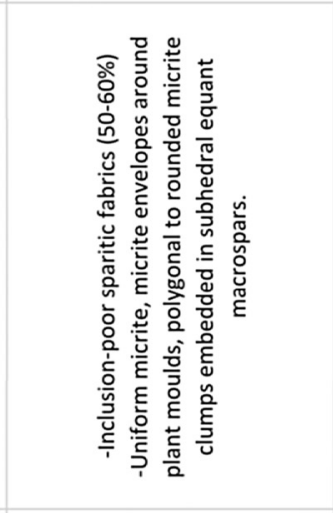 & 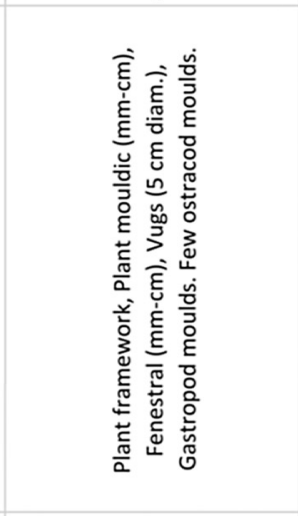 & 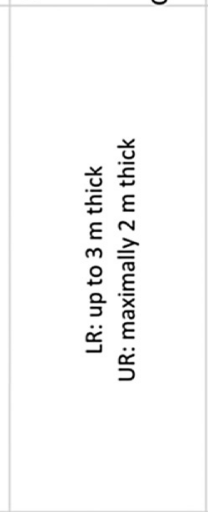 & \\
\hline & 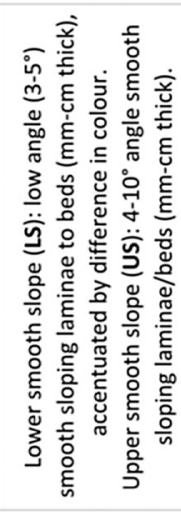 & क & 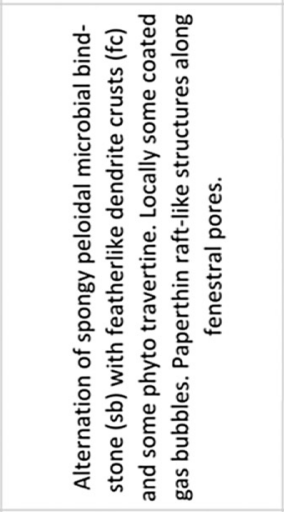 & 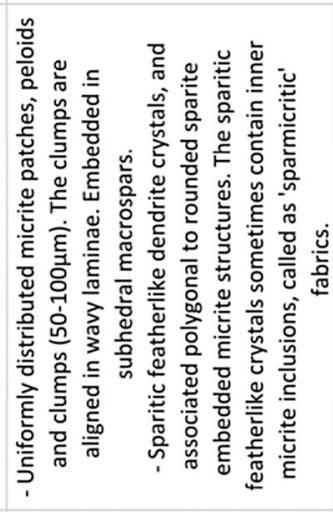 & 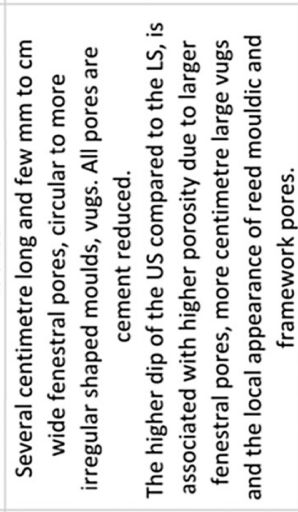 & 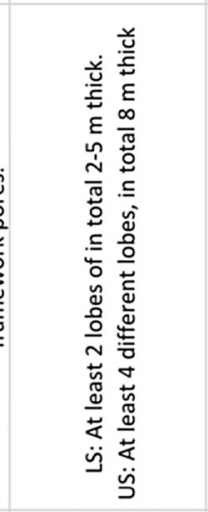 & \\
\hline & 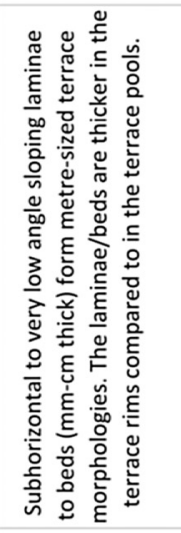 & (f) & 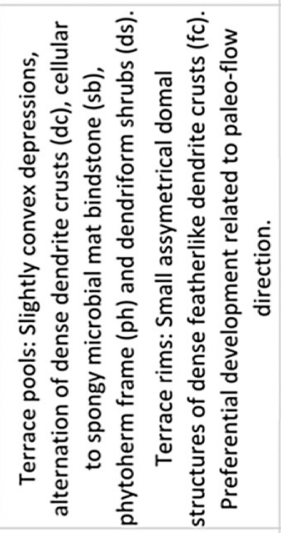 & 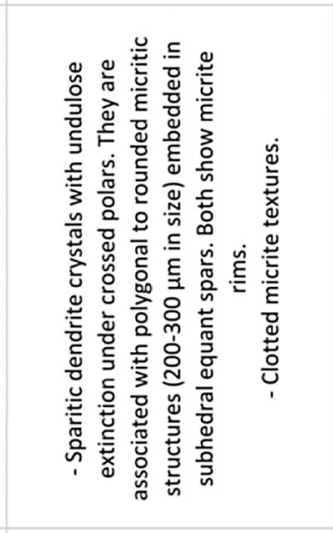 & 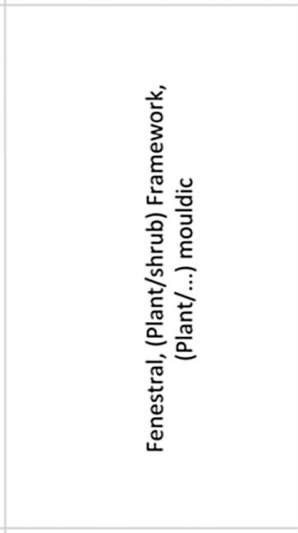 & 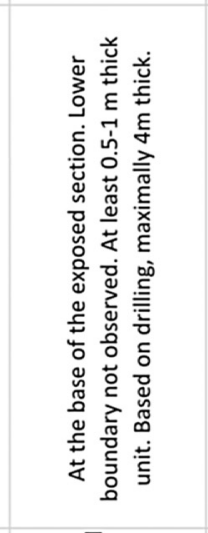 & $\begin{array}{l}\overrightarrow{0} \\
\dot{0}\end{array}$ \\
\hline 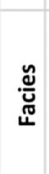 & 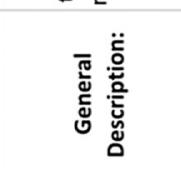 & & 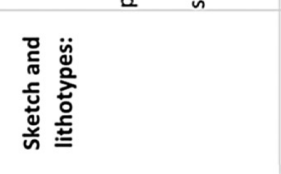 & 䓌 & 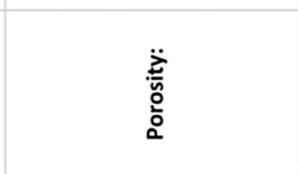 & 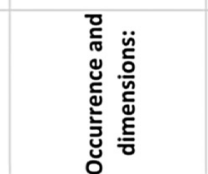 & \\
\hline
\end{tabular}


horizontal core plugs. The results confirm the representative sampling, where the isotropic porosity does not change for a different orientation. Permeability can, however, strongly vary because of the different encountered heterogeneities related to the direction of the measurements. Unfortunately, only 2 representative samples of the terrace facies, in which this anisotropy is most pronounced, were included. For two samples with a porosity of $10 \%$, there is an equivalent permeability difference of more than 4 orders of magnitude ( $0.05 \mathrm{vs}$. $3960 \mathrm{mD}$ ). The effect is equally clear for the smooth slope facies that are characterized by moderate porosity values (i.e. 13\%). Their permeability values are bimodal, exhibiting both low (i.e. $0.03-0.43 \mathrm{mD}$ ) and high (i.e. $684-18,400$ $\mathrm{mD}$ ) permeability values (Fig. 12). The latter values mostly are observed for horizontally oriented core plugs exhibiting pronounced laminar porosity, like the spongy peloidal bindstone. Visualisation by $\mu \mathrm{CT}$ analysis of these plugs reveals pores that are elongated along the core plug direction and sometimes even connect the core plug ends. These porous layers alternate with more massive low-porous dendrite crust layers (e.g. Figs. 4D, 5AC). Vertically oriented core plugs with alternating more massive and more porous layers resulted in relatively low permeability values. For vertically oriented core plugs with elevated permeability, $\mu \mathrm{CT}$ analysis revealed that vuggy layers are connected to each other with preserved meso-porosity existing in the denser interlayers.

The higher porosity observed during the fieldwork for the higher angle smooth slope facies is to some extent confirmed by the measured porosity data, i.e. an average porosity of $\sim 11 \%$ versus $\sim 13.5 \%$ for the lower and upper smooth slope facies, respectively. The difference is most pronounced in two core plugs that display more porous fabrics. In the sample with higher porosity and still low permeability, separate mouldic pores between more massive fabrics are present. The sample with both high porosity and permeability has a presence of partially solution enlarged large vugs in the middle part of the core plug, as revealed by $\mu \mathrm{CT}$ analysis. Larger cavities, however, are not incorporated in the core plug dataset.

The reed facies displays relatively high porosity values, ranging from 5.2 to $27 \%$ (mean value $=15.26 \%$ ). Permeability values for horizontally oriented core plugs are clearly much higher, as the
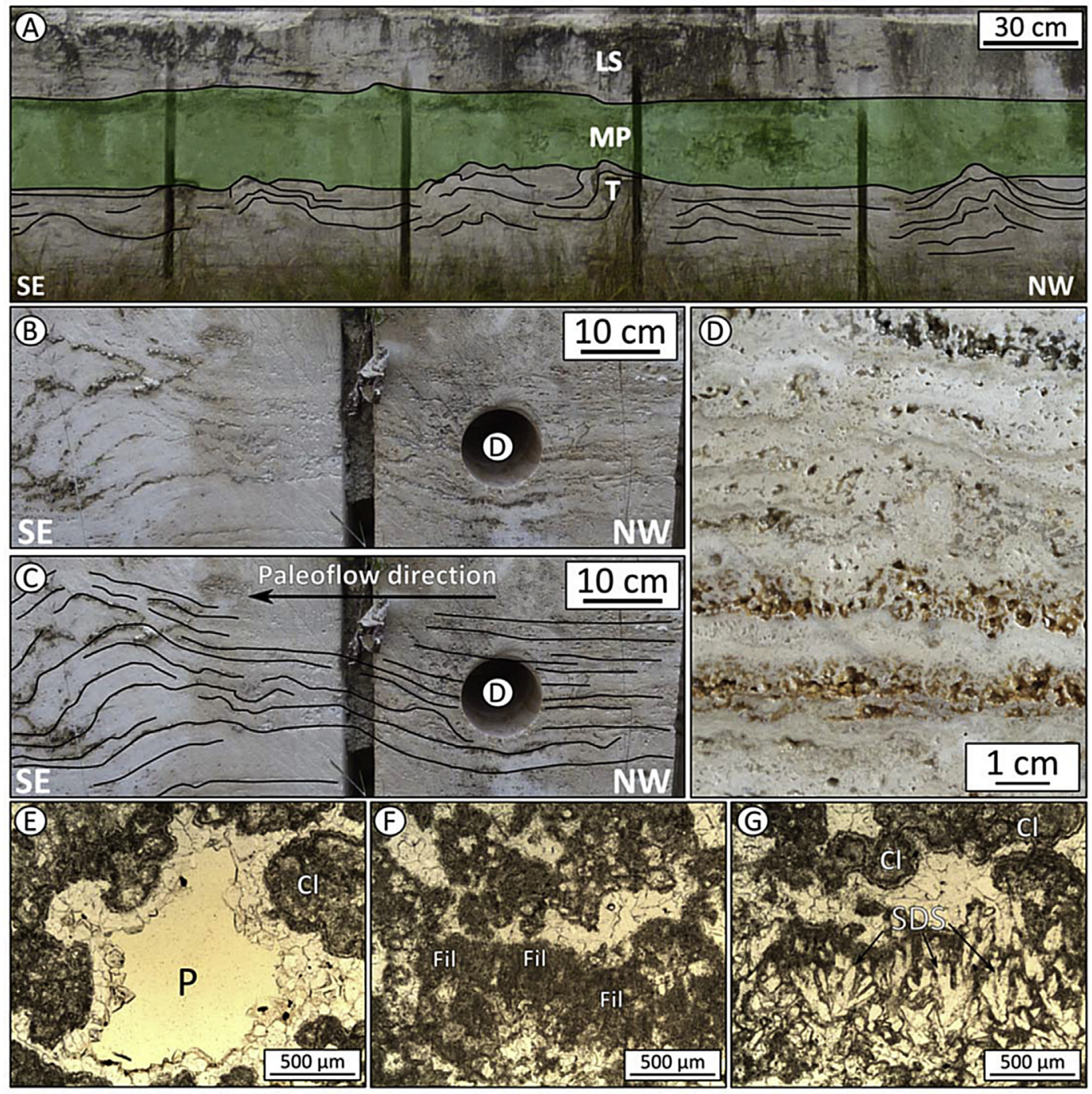

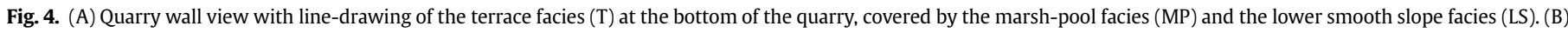

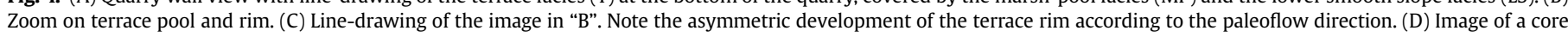

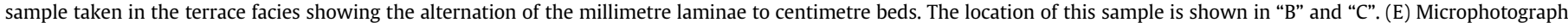

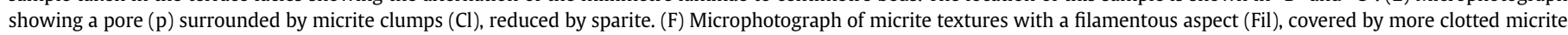
textures. $(\mathrm{G})$ Microphotograph of sparitic dendritic shrubs (SDS) with micrite envelopes. 
phytoherm framework and the phytoclastic fabrics exhibit an alternation of highly porous layers (i.e. highly irregular shaped, well-connected pores which regularly show a mouldic to framework origin) and more massive layers (though less pronounced than in the lower smooth slope facies; Fig. 13). Permeabilities for vertically oriented core plugs of the reed facies are generally higher relative to the smooth slope facies, as dense and cemented massive layers are less well developed. Permeability, generally, is mainly controlled by the phytomouldic pore networks, which are not always continuous along the entire core plug. In the upper reed facies the spongy peloidal bindstones show a higher porosity with a better connection mostly in the horizontal direction. Moulds cross-cutting this horizontal orientation lead to an additional good vertical connectivity. This results in the pronounced high porosity and permeability values that were measured for the upper reed facies.

The core plugs of the marsh-pool facies possess relatively low porosities $(6.8-17.1 \%$, mean value $=10.0 \%)$ though they are characterized by relatively high permeabilities $(3-500 \mathrm{mD})$. The CT scans of core plugs and cores from this facies show the presence of abundant elongated pores (Fig. 11L), of which most run along the length of the core plug. Furthermore separate vugs (sensu Lucia, 1983) are present. Several of these core plugs also display patches of porous fabrics in a more dense rock framework (Fig. $11 \mathrm{~K}$ ), which may also have contributed to the connectivity of the pore network.

\section{Discussion}

\subsection{Geobody architecture and lithofacies}

Based on outcrop characteristics and macroscopic observations it is possible to differentiate several travertine lobes within the central part of the quarry (similar to Violante et al., 1994). Based on these, the 3D geobody architecture was reconstructed (Fig. 14). The slopes, thickness changes of the different lithofacies and the presence of sedimentary structures (e.g. terraces and orientation of plant relicts) indicate the paleoflow directions. Together with the overall geobody architecture, they support a dominant flow direction varying between NE and SE (Fig. 14). The location of the vent(s), or source area of the central quarry part, thus has to be searched in the opposite direction. The paleoflow directions deduced from the quarry walls are in accordance with the local orientation of the mapped travertine body: away from the morphologically deduced fault. This, together with the paleoflow directions deduced from the older walls and borehole descriptions (Scheuer et al., 1987), allowed constructing a conceptual model of the whole Budakalász travertine body (Fig. 15). This conceptual model is in good accordance with the simplified model of Scheuer and Schweitzer (1985). For the individual lobes, the morphology is similar to those described by Violante et al. (1994), in which multiple suspended 'channels' distributed the water and where the lobes were formed due to changes in discharge and flow path of the precipitating
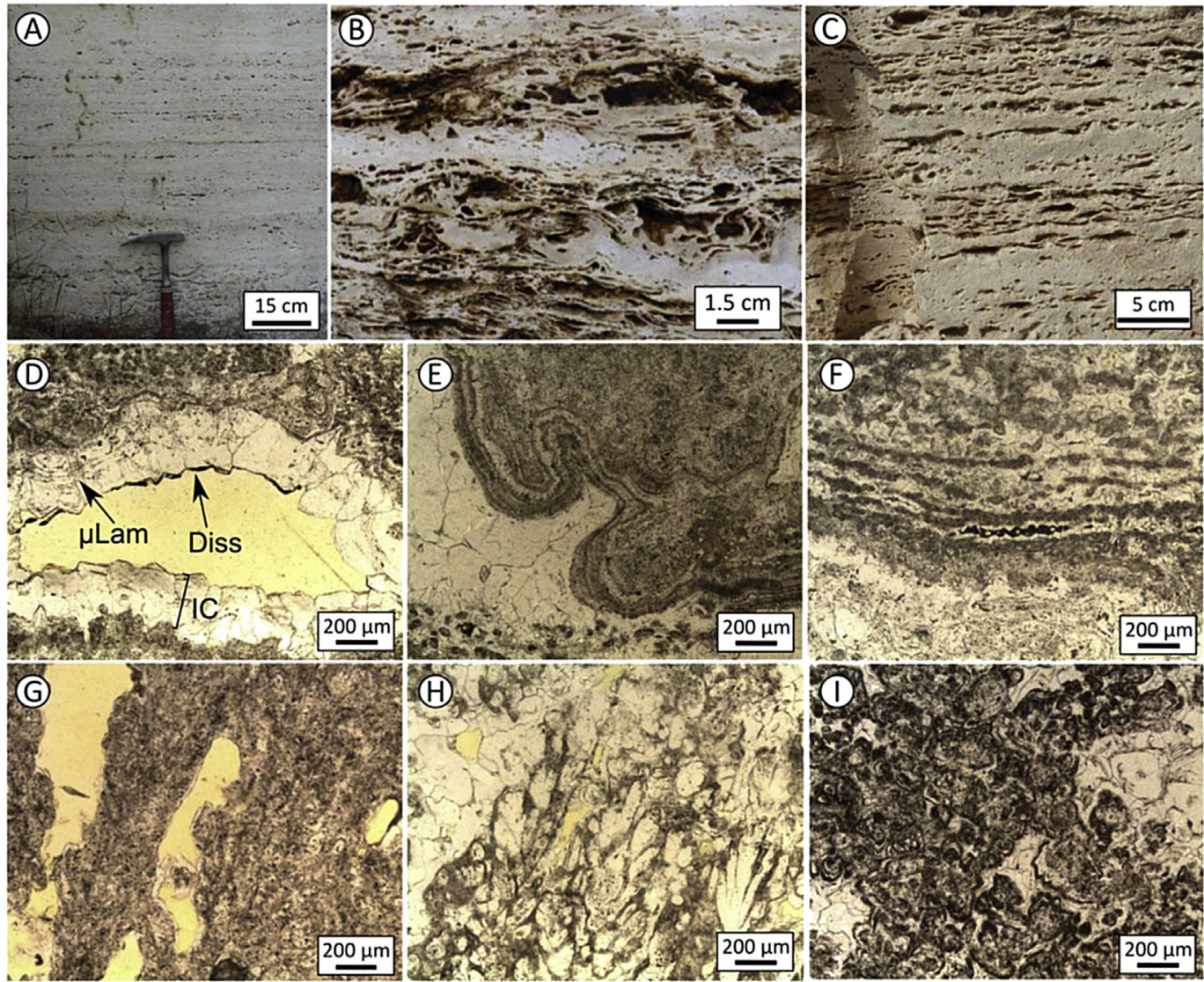

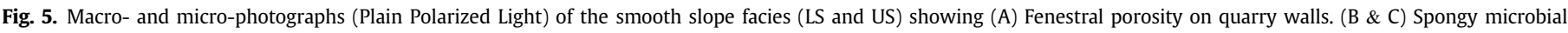

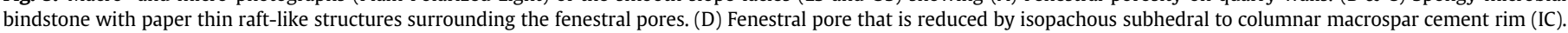

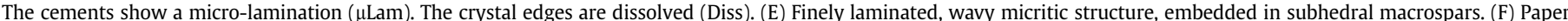

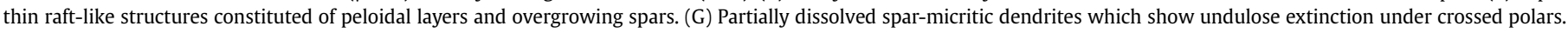
(H) Sparitic dendrites, covered with a micritic envelope. (I) Polygonal to rounded micritic structures sometimes displaying rhomb-shaped outline. 
waters. The lobes can be distinguished based on the occurrence of exposure surfaces, discontinuities in slope angle and facies boundaries. Within the lobes, the different lithofacies represent different depositional environments.

Terrace and smooth sloping facies have been described for travertines, both in active settings (e.g. Jamtveit et al., 2006; Kele et al., 2011) as well as in fossil settings (e.g. Guo and Riding, 1998; Pola et al., 2014). Compared to the facies described in literature, the observed slope angles in Budakalász (3-10 ) are, however, much lower in contrast to e.g. $10-40^{\circ}$ slope angles reported in Rapolano Terme (Guo and Riding, 1998). The Budakalász terrace pools and rims are also in the smaller range (respectively, $m$ and up to dm scale) compared to literature data. Similar to previously reported cases terrace rims are formed by featherlike dendrite crusts, while terrace pool lithotypes are highly variable, with cyclic alternations between dendrite crusts, shrub, phytohermal and phytoclastic travertines. The featherlike dendritic crusts form typically in laminar fast-flowing water by rapid precipitation at sites of high $\mathrm{CaCO}_{3}$ supersaturation (e.g. Guo and Riding, 1998; Chafetz and Guidry, 1999; Gandin and Capezzuoli, 2014).

The lithotypes of the observed Budakalász smooth slope facies are not completely in agreement with the ones from for example the Rapolano travertine body and do not dominantly consist of the reported 'crystalline crusts' (Guo and Riding, 1998). The dominant lithotype of the Budakalász smooth slope travertines consists of spongy microbial bindstone. The ovoid shape of the fenestral porosity, in combination with the absence of supporting fabrics for the micritic raft-like textures, suggest decay or dissolution of an earlier supporting substrate. Based on comparison with literature data these are formed by decay of microbial mats in combination with processes of dessication (e.g. Gandin and Capezzuoli, 2014). In addition, phytohermal and phytoclastic travertines occur. They illustrate that, despite fast precipitation (clear from the occurrence of crusts), a high control by microbes and plants on the precipitation existed.

The reed and marsh-pool facies described here correspond to two variants of the marsh-pool facies described by Guo and Riding (1998), in which phytohermal and phytoclastic travertines, lithoclasts and pedogenesis effects are widespread and ostracods and gastropods are common. The reed facies, with a high occurrence of reed mouldic porosity, was already distinguished from other marsh-pool facies in Claes et al. (2015a). The biostromal reed facies is there described as being formed in 'a setting with small ponds and rivers and temporarily and/or locally incipient soil formation'. It can also be considered similar to the 'macrophyte facies' of Rainey and Jones (2009) that formed where 'local vegetation was inundated by
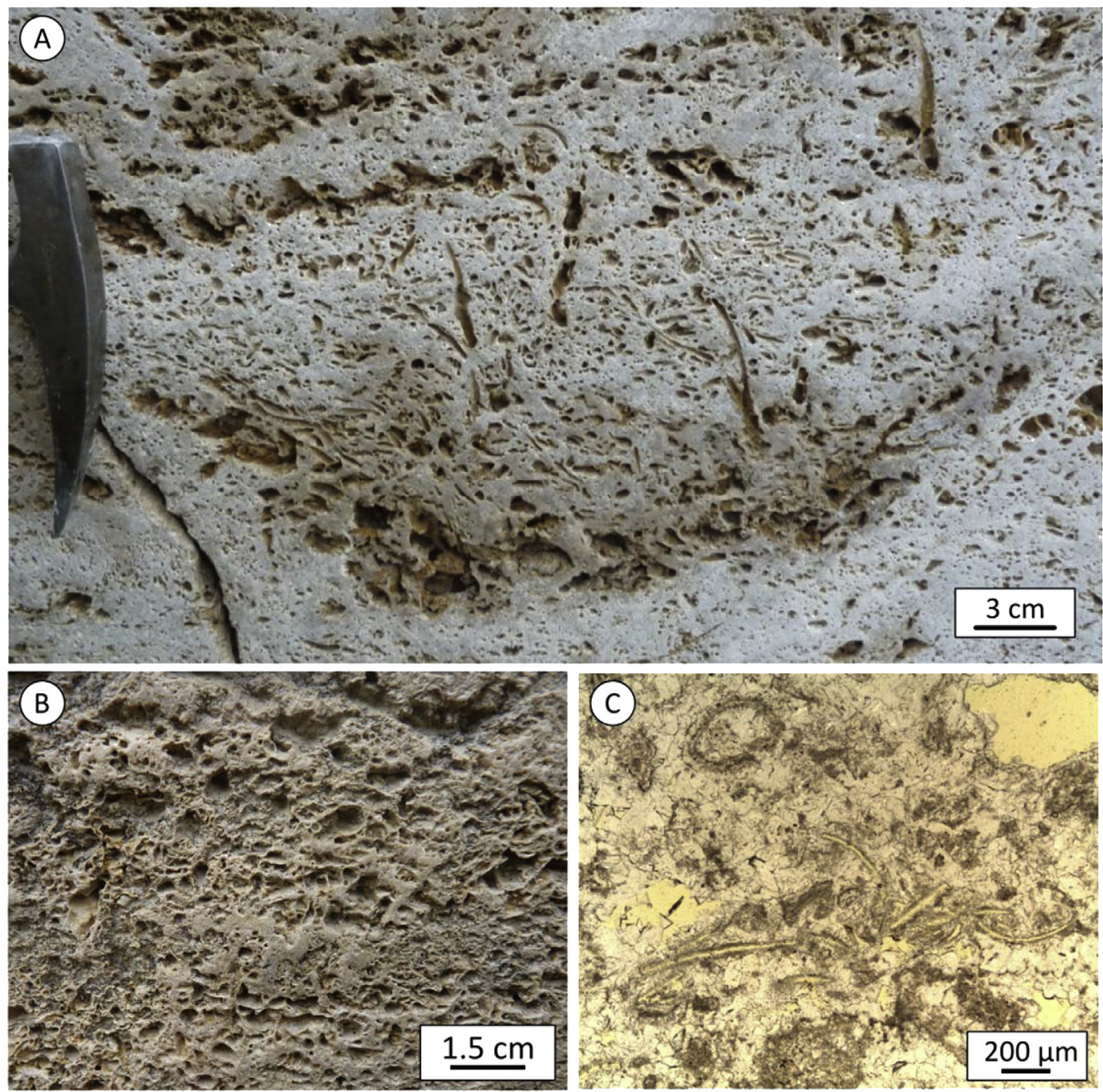

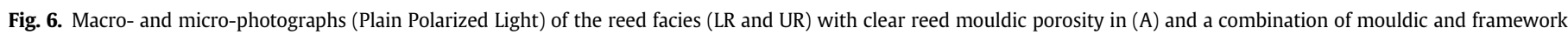
porosity in (B). (C) Sparite dominated nature of the fabrics with reed moulds of the reed facies. 
spring water and encrusted with calcite'. For the marsh-pool facies of Budakalász, the vertically elongated pores associated with the gastropods could well be the result of bioturbation. Alternatively, they may also be root moulds. The presence of charophytes and gastropods supports a low energy environment and relatively ambient temperature (Shukla et al., 2002). Very similar fabrics and conditions were also described from lacustrine environments (e.g. Freytet and Verrecchia, 2002; Shukla et al., 2002). For example the lacustrine limestone of Beauce, also referred to as the Pierre de StFiacre, consist of bioturbated biomicrite rich in ostracods, charophytes, algal-bacterial encrustations and traces of pedogenesis (Freytet and Verrecchia, 2002). These limestones are typical for palustrine to shallow lacustrine environments. The marsh-pool facies of Guo and Riding (1998) is described as forming distally from the sources of hot springs. Also Gandin and Capezzuoli (2014) considered the lime-mudstone as being formed in rain-diluted waters in palustrine settings, commonly located on distal unconformable surfaces'. This concept is applicable for the first and second occurrence of the marsh-pool facies (Fig. 3; Table 1). However, in the top of the Budakalász section they were relatively closer to the supposed source, and the occurrence is more likely related to the decline of the spring activity, i.e. as the closing stage of travertine formation (cfr. Kele et al., 2003). Similar to the occurrence of the different travertine terraces related to the incision of the Danube river in the uplifting Buda Hills (Ruszkiczay-Rüdiger et al., 2005), also the ceasing of the Budakalász travertine system can be related to tectonic uplift (Scheuer and Schweitzer, 1974).

In general the sequence represents an evolution from a sloping travertine to a palustrine-lacustrine system. The initial terrace system evolved to a palustrine system resulting in the first marshpool facies occurrence, before a temporary precipitation stop occurred, as evidenced by the erosional surface. Renewed precipitation results in smooth sloping travertines, that gradually became steeper. Overlapping travertine lobes are a direct consequence of changes in discharge and flow paths. In addition to this vertical transition, also important (intra-lobe) lateral facies changes were observed. As observed in active systems (e.g. Fouke et al., 2000) there is a transition in lithofacies with distance from the vent. The slightly steeper smooth sloping facies are marked by waving lamination/bedding and are associated with irregular laminae textures and large cavities and grade into the lower angle smooth sloping travertines with more straight laminae (e.g. Fig. 3). Several smaller wedge shaped structures were distinguished. The wedges form an onlap on previous deposits and thus reflect a smooth relief. Towards the top of the system more and more plants were able to grow within the precipitation area, possibly reflecting lower temperatures and lower precipitation rates. The upper smooth slope facies and lower reed facies wedge out up-stream. From the reed facies towards the top of the upper marsh-pool facies, the system ceases completely. During the whole activity period of the system, a more distal marsh-pool facies formed (Fig. 14). The 'fossil' lithofacies that are currently exposed in the lobes on the outcrop can thus be considered as part of the pond, proximal slope and distal slope travertine facies as defined in active settings (Fouke et al., 2000; Fouke, 2011).

Outcrop analogues are used to gather data on the dimensions, shapes and orientations of structures and geobodies which are crucial for reservoir modelling (Jung and Aigner, 2012). Other studies characterised the internal architecture of domal or mound travertine bodies (e.g. Pola et al., 2014; Claes et al., 2015a), fissure ridge travertines (e.g. Gradzinski et al., 2014), wedge-shaped valley fill travertines (e.g. Arenas et al., 2014; Huerta et al., 2016) and a mixed travertine-terrigenous system (Croci et al., 2016) have been reported. The overall geobody of the Budakalász travertines was described as a mound/fissure ridge complex (Scheuer and Schweitzer, 1985; Pentecost, 2005). Based on Jung and Aigner (2012), the depositional shape should rather be classified as fans or lobes (see 3D sections, e.g. Fig. 15). In the existing travertine geobody classifications (latest by Della Porta, 2015) they can be placed in the group of 'Aprons, fans and wedges with smooth and terraced slopes and horizontally layered ponds'. The Budakalász travertines can be considered the prime example of a travertine lobe complex. Based on the shape and mapped dimensions, a total travertine volume of $\sim 3 \times 10^{6} \mathrm{~m}^{3}$ is estimated. The main geobody
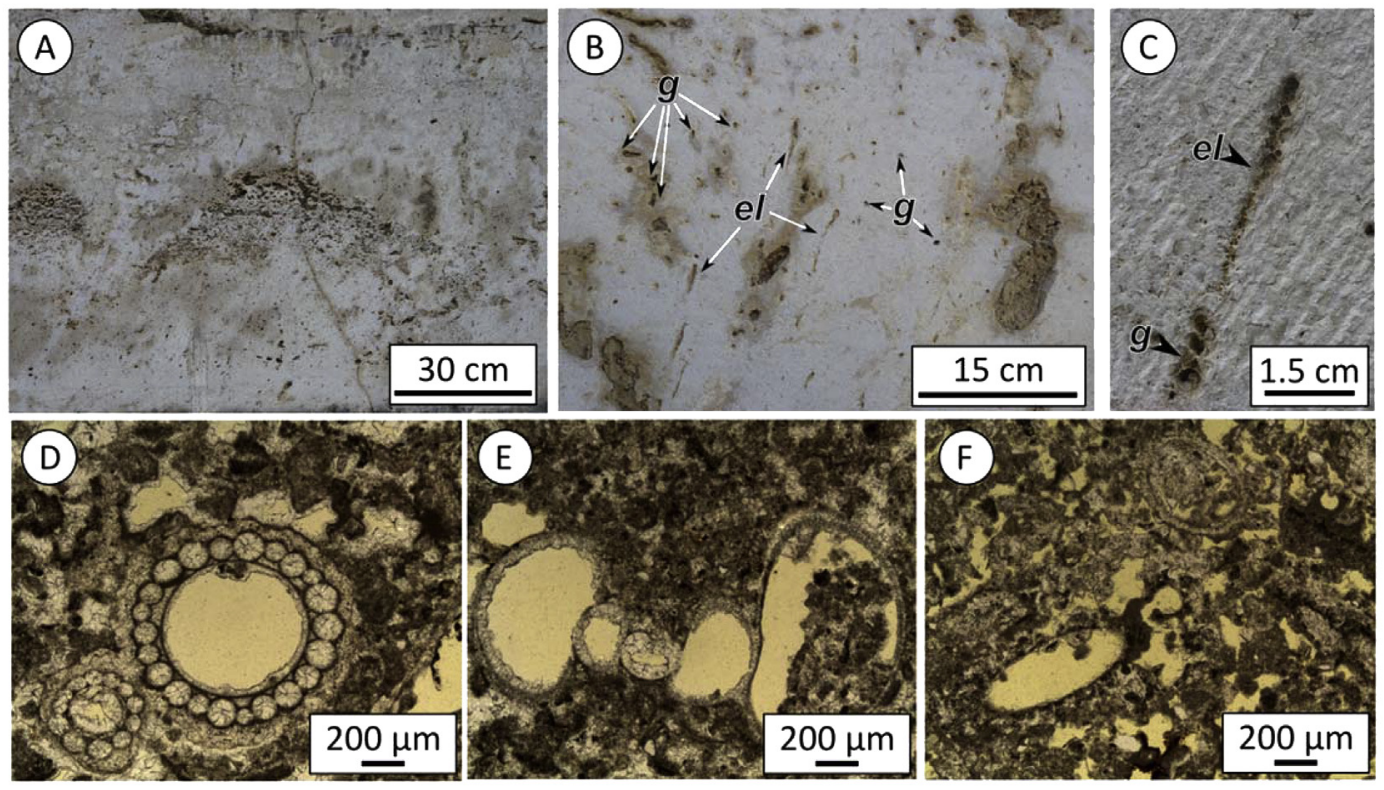

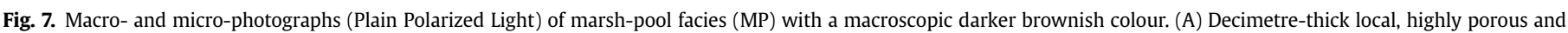

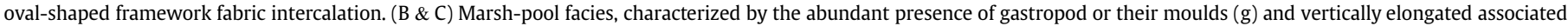

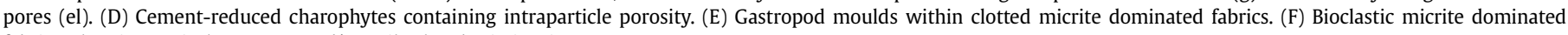
fabrics, showing typical exposure and/or soil related micrite rims. 

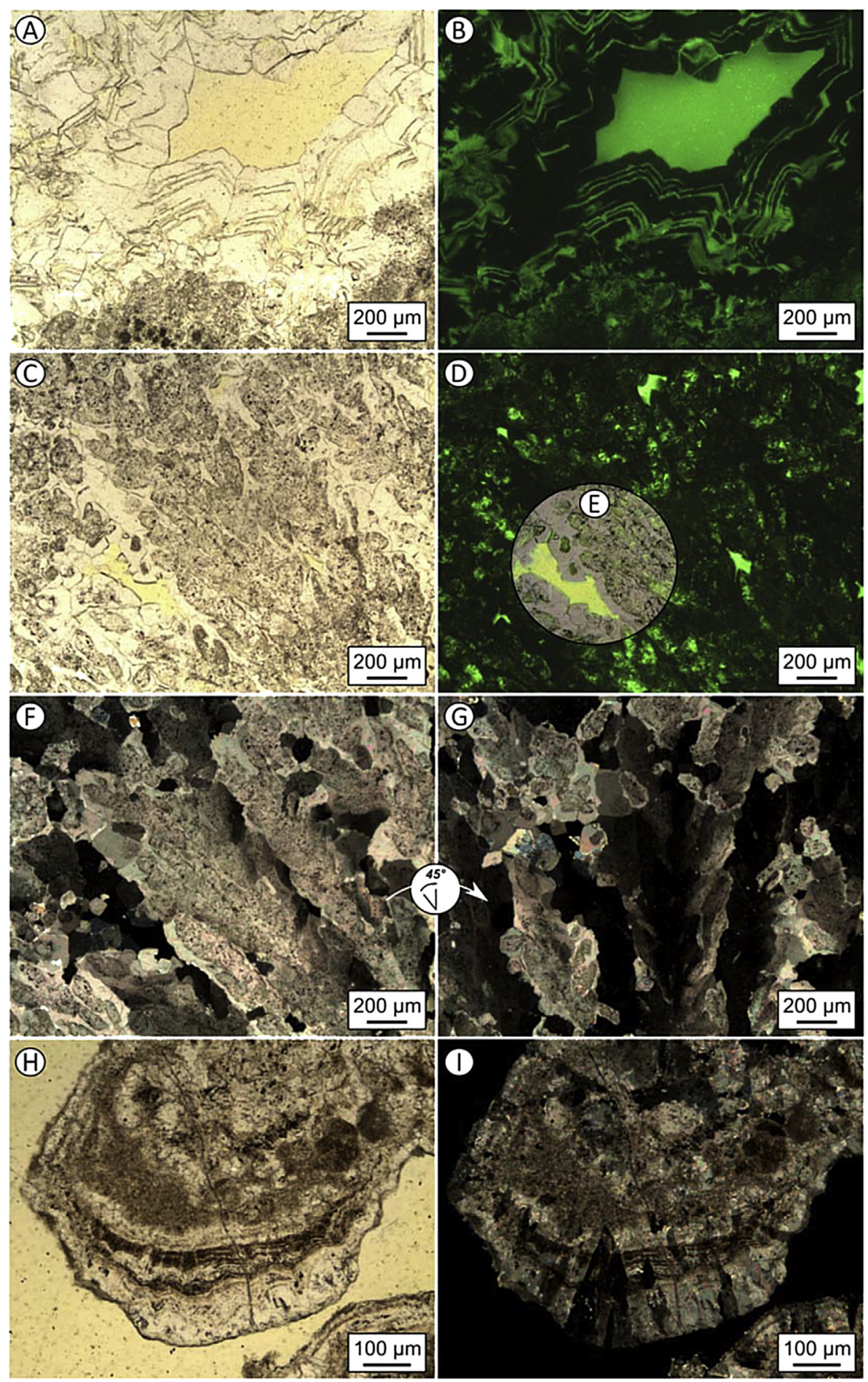

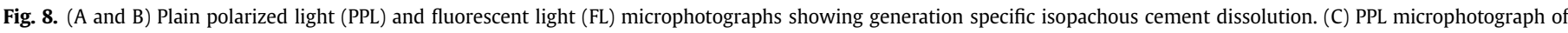

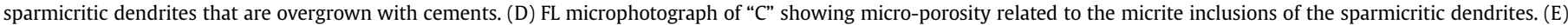

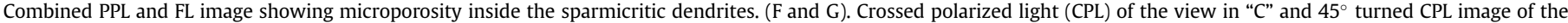

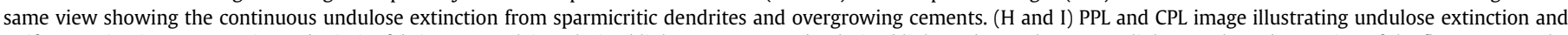

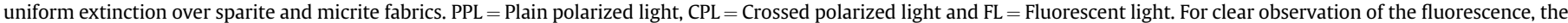
reader is referred to the web version of this article.

outline is determined by topography and gravity (in line with Jung and Aigner, 2012). The individual lobe shape and growth style is determined by the aggradation/progradation ratio, where discharge and water velocity are inversely correlated with this ratio (Arenas et al., 2014).

\subsection{Diagenesis}

Primary fabrics in travertines in general consist of micrite, sparite or a combination of both. Post-formation processes may cause micritisation (e.g. Kahle, 1977; Chafetz et al., 1994; Guo and 


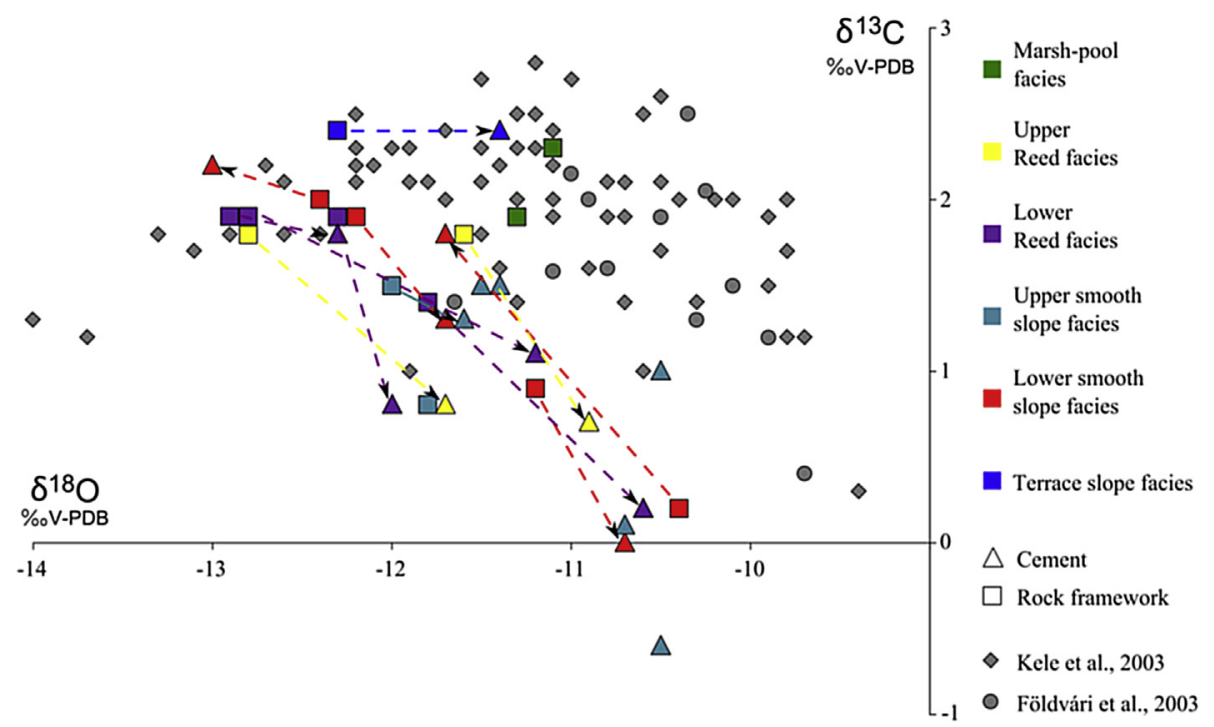

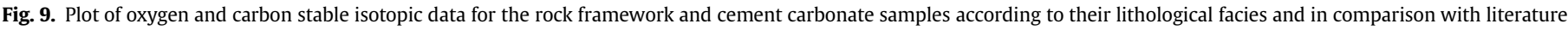
data from Kele et al. (2003) and Földvári et al. (2003). (For interpretation to colour in the figure, the reader is referred to the web version of this article.)

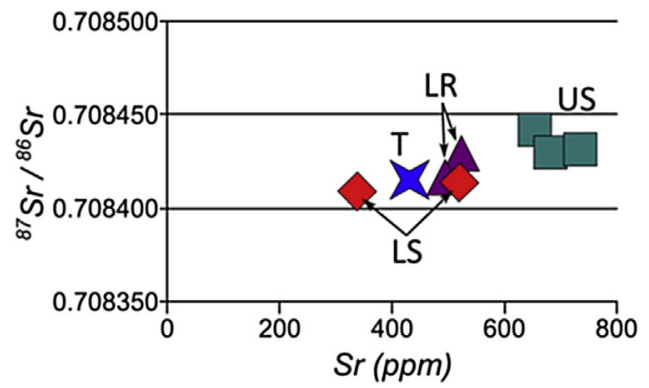

Fig. 10. Plot of ${ }^{87} \mathrm{Sr} /{ }^{86} \mathrm{Sr}$ ratios versus $\mathrm{Sr}$ concentrations. $\mathrm{T}=$ Terrace slope facies, LS $=$ Lower smooth slope facies, US = Upper smooth slope facies, LR = Lower reed facies.

Riding, 1994; Nicoll et al., 1999;; Rainey and Jones, 2007) or sparitisation (e.g. Love and Chafetz, 1988; Freytet and Verrecchia, 1999; Golubic et al., 2008;; Brasier et al., 2011). This results in highly complex fabrics, where it is often challenging to distinguish primary from secondary fabrics (Pentecost, 2005; Pedley, 2009; Brasier et al., 2015; Claes et al., 2015a). In addition, these processes are starting immediately after first precipitation (e.g. Guo and Riding, 1994; Arp et al., 2001), meaning that they are syndepositional, but, given the susceptible aragonite or calcite mineralogy, continue up to the moment the sample is studied under the microscope. Moreover, diagenesis proceeds unevenly often conditioned by the porosity of the deposit (Golubic et al., 2008). Rather than the distinction between 'depositional' and 'diagenetic' fabrics, focus should lie on understanding the processes involved from the moment of deposition onwards.

One of the earliest diagenetic processes immediately after carbonate precipitation is organic decay. Porosity development in continental carbonate deposits is strongly related to microbes (e.g. Chafetz, 2013) and physical-chemical precipitation upon macrophytes (e.g. Soete et al., 2015), producing characteristic, highly porous laminar, mouldic and framework pore types. This is also the case for the Budakalász travertines, characterised by the macroscale porosity types e.g. in the spongy microbial bindstones (e.g. Fig. 5B and $\mathrm{C}$ ) and the phytoherm and phytoclastic lithotypes (e.g. Fig. 6A, $B$ and $C$ ), making organic decay one of the processes with the visually highest impact. The decay rate of organic matter in travertine is dependent on the oxygen availability (Pentecost, 2005).

Recrystallisation also starts shortly after precipitation (e.g. Arp et al., 2001). As to mineralogy, the Budakalász travertine fabrics presently are composed of pure calcite (Soete et al., 2015), apart from some detrital quartz grains in the marsh-pool facies. No indications of other carbonate mineralogies have been noticed, therefore, it is very likely that the original mineralogy consisted also of low-Mg calcite. Undulose extinction affecting different crystals (Fig. 8F-I) indicates either syntaxial overgrowth or recrystallisation. Aggradational neomorphism is the most widely reported type for recrystallisation in travertines (Love and Chafetz, 1988; Freytet and Verrecchia, 1999; Janssen et al., 1999; Nicoll et al., 1999; Pentecost, 2005). The driving process would be Ostwald ripening where, for increasing crystal size, the specific surface free energy of the crystals would reduce (Love and Chafetz, 1988). Brasier et al. (2011), however, argued that in order for Ostwald ripening to occur, temperatures in the order of $500{ }^{\circ} \mathrm{C}$ are necessary, and this preferably in closed system conditions. For porous travertines that were never substantially buried, reduction of crystal specific free surface energy was thus more likely caused by post-depositional crystal growth, where crystals nucleate upon precursor crystals (Brasier et al., 2011). The processes behind syntaxial overgrowth and eo-diagenetic neomorphic recrystallisation of travertines might thus be very similar. Depending on the stage of 'recrystallisation' it could be difficult to distinguish them from one another (e.g. Fig. 8C-G). The occurrence of both processes, however, can be derived from the continuous undulose extinction over different crystals (Fig. 8C-I). The disappearance of the crystal edges of the precursor crystals can be used as an argument for recrystallisation (Fig. $8 \mathrm{H}$ and I).

The two main causes of micritisation in travertines are microboring activity and (micro-) dissolution (Guo and Riding, 1994). In the Budakalász travertines, two micrite fabric types are indicative for micritisation. Firstly, there are several structures covered by a micritic envelope, clearly illustrated in Figs. 4H and 5G. This kind of micrite envelopes is typically formed by microboring (or microetching cfr. Pentecost, 2005) of dendritic spars (Kahle, 1977; Chafetz et al., 1994). The second micrite fabrics related to micritisation are found as micrite patches in cloudy sparite crystals that laterally occur together with clean sparite crystals. These crystals 

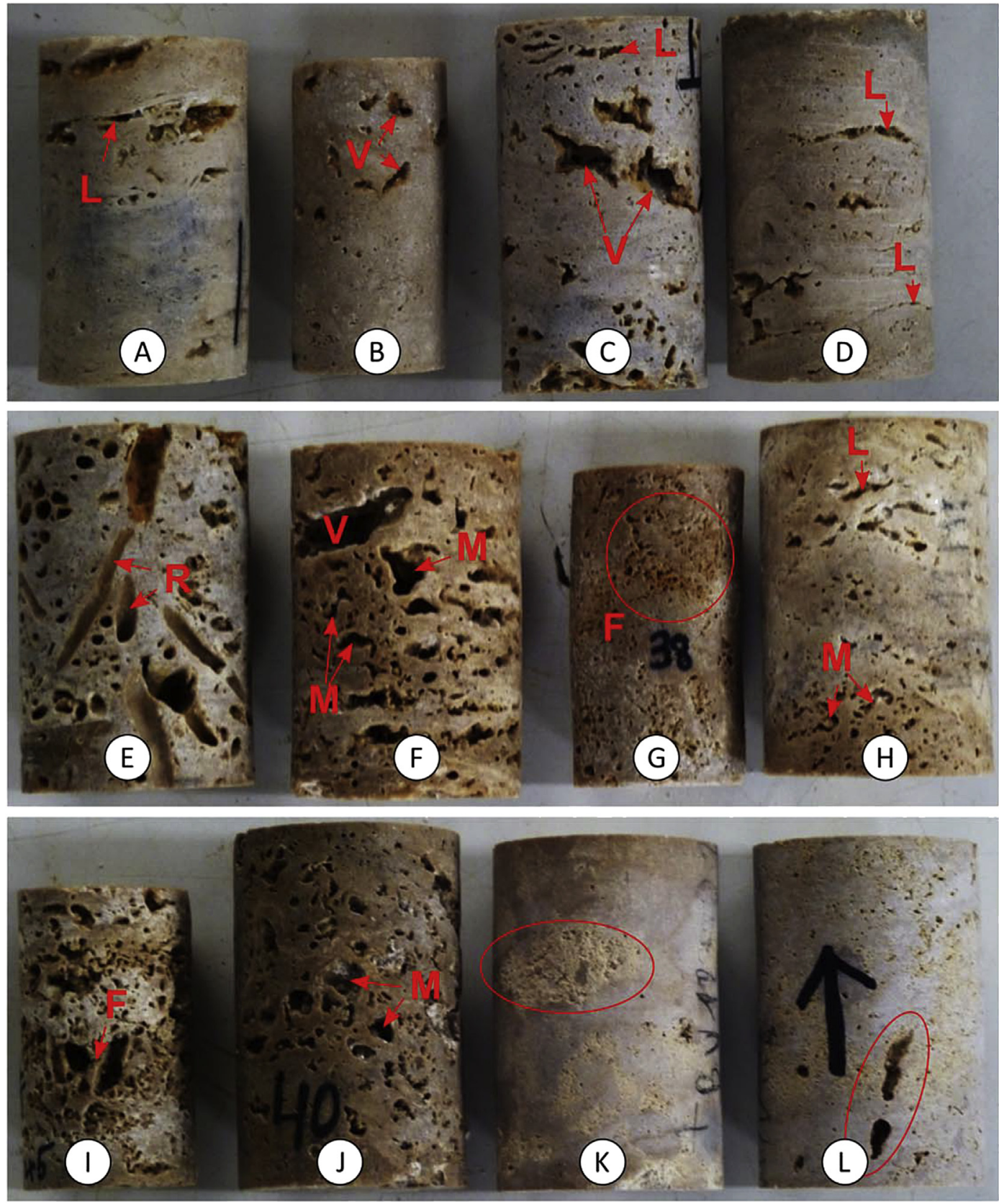

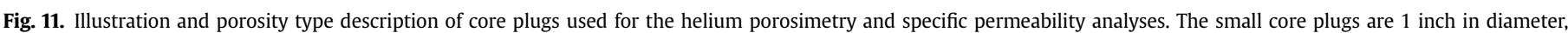

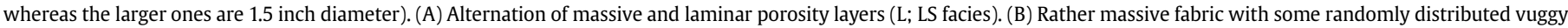

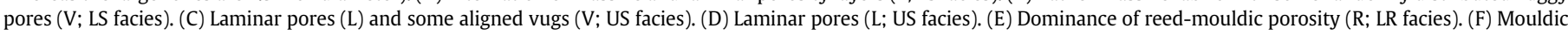

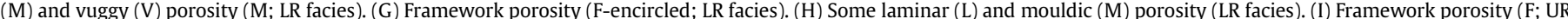

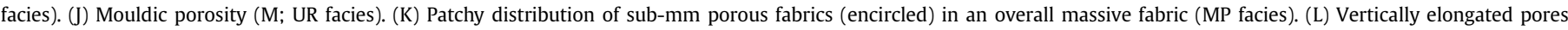

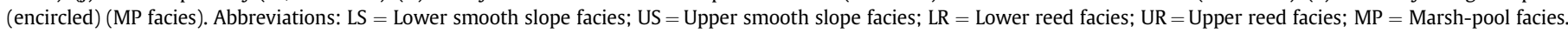

represent a range in degree of sparmicritization as reported by Chafetz et al. (1994). The latter authors relate the patchy micrite to micro-boring activity. Although, the rounded nature of some of the micrite patches (e.g. Fig. 8C) might be an argument in favour of micro-boring activity, the micrite inclusion-rich sparites are associated with remarkable micro-porosity development (Fig. 8D, E). Repeated dissolution led to interior pores resulting in crystal breakdown and apparent micritisation of sparite crystals (Kahle, 1977; Guo and Riding, 1994). Concomitant dissolution of sparite and precipitation of micrite has been reported to be much more common than micro-boring activity (95 vs. 5\%; Kahle, 1977), but plausibly both processes occurred in the Budakalász travertines. Micro-boring activity can readily destroy the clear sparites when exposed (Ford and Pedley, 1996). Particularly in the marsh-pool facies micritic coatings are widespread (Fig. 7). Dissolution and micro-boring activity are both typically found in calcretes, i.e. related to exposure (Tucker and Wright, 1990).

Several cementation phases have been recognised reducing the largest pores and completely occluding the smallest pores. Sparites thus vary from primary depositional (e.g. sparitic dendritic shrub crusts; Figs. $4 \mathrm{G}$ and $5 \mathrm{H}$ ), over syn-depositional, to post-depositional (e.g. Fig. 8). On the macro-scale, however, pore reducing 


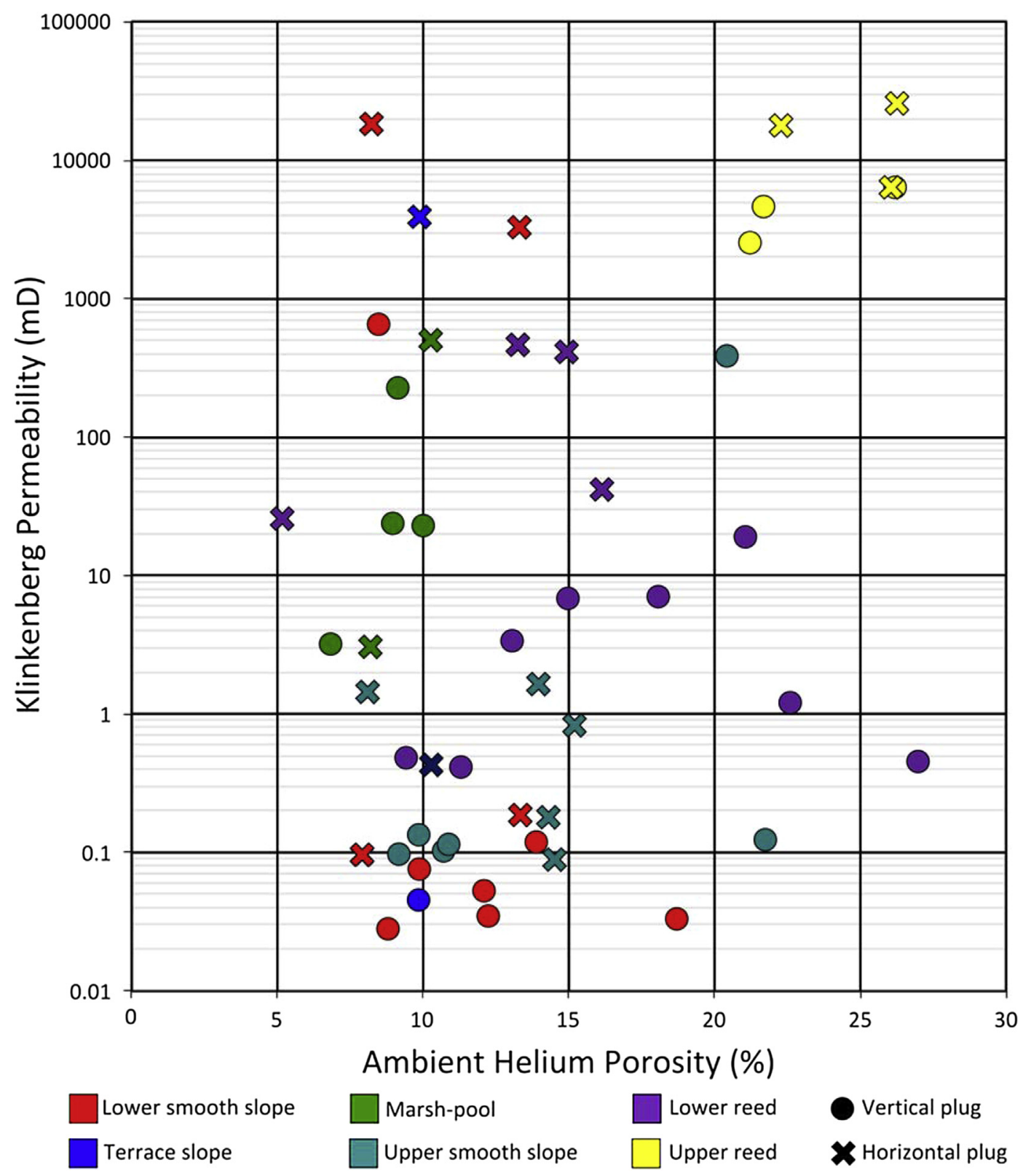

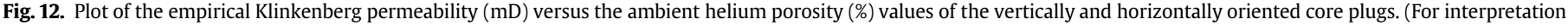
of the colour in this figure, the reader is referred to the web version of this article.)

cementation seems to be rather limited, considering that waters oversaturated with respect to calcite existed in these systems. Cementing sparites show rounded edges, indicating late-stage minor dissolution. In general, this gives a more rounded, i.e. vuggy, appearance to all pore types.

The isopachous nature of the different generations of cementing subhedral equant to columnar spars are typical for phreatic conditions, related to subsurface water percolation in travertine systems. Not only the cementation but also other diagenetic processes will be dependent on the contact of the rocks with percolating waters, i.e. their proximity to conduits (Golubic et al., 2008). High permeable lithologies, e.g. spongy microbial bindstones in the smooth sloping facies and phyto lithotypes in the reed facies, will thus be more susceptible to diagenetic overprinting. Dense lithologies, like the dendrite crusts, would be expected to represent always the most pristine fabrics. Careful petrographic evaluation, for example for absence of cloudy textures associated with microporosity, is a necessity in order to identify these pristine fabrics. Given the dominance of the sparite fabrics for most Budakalász lithotypes, and taken into the account the reported diagenetic fabrics, the 'primary' fabrics were dominated by sparites. The lime mudstones of the marsh-pool facies can be considered an exception, with a higher occurrence of 'primary' micrite.

\subsection{Strontium isotopes}

All the analysed travertines are characterized by low ${ }^{87} \mathrm{Rb} /{ }^{86} \mathrm{Sr}$ ratios $(<0.004)$, with no correlation between the ${ }^{87} \mathrm{Rb} /{ }^{86} \mathrm{Sr}$ and ${ }^{87} \mathrm{Sr} /{ }^{86} \mathrm{Sr}$ ratios. This implies that the ${ }^{87} \mathrm{Sr} /{ }^{86} \mathrm{Sr}$ ratios of the travertines are not influenced by in-situ decay of ${ }^{87} \mathrm{Rb}$ and thus their uniform Sr isotopic signature (0.70841-0.70844) directly reflects the $\mathrm{Sr}$ isotopic composition of their precipitating fluids (Minissale 

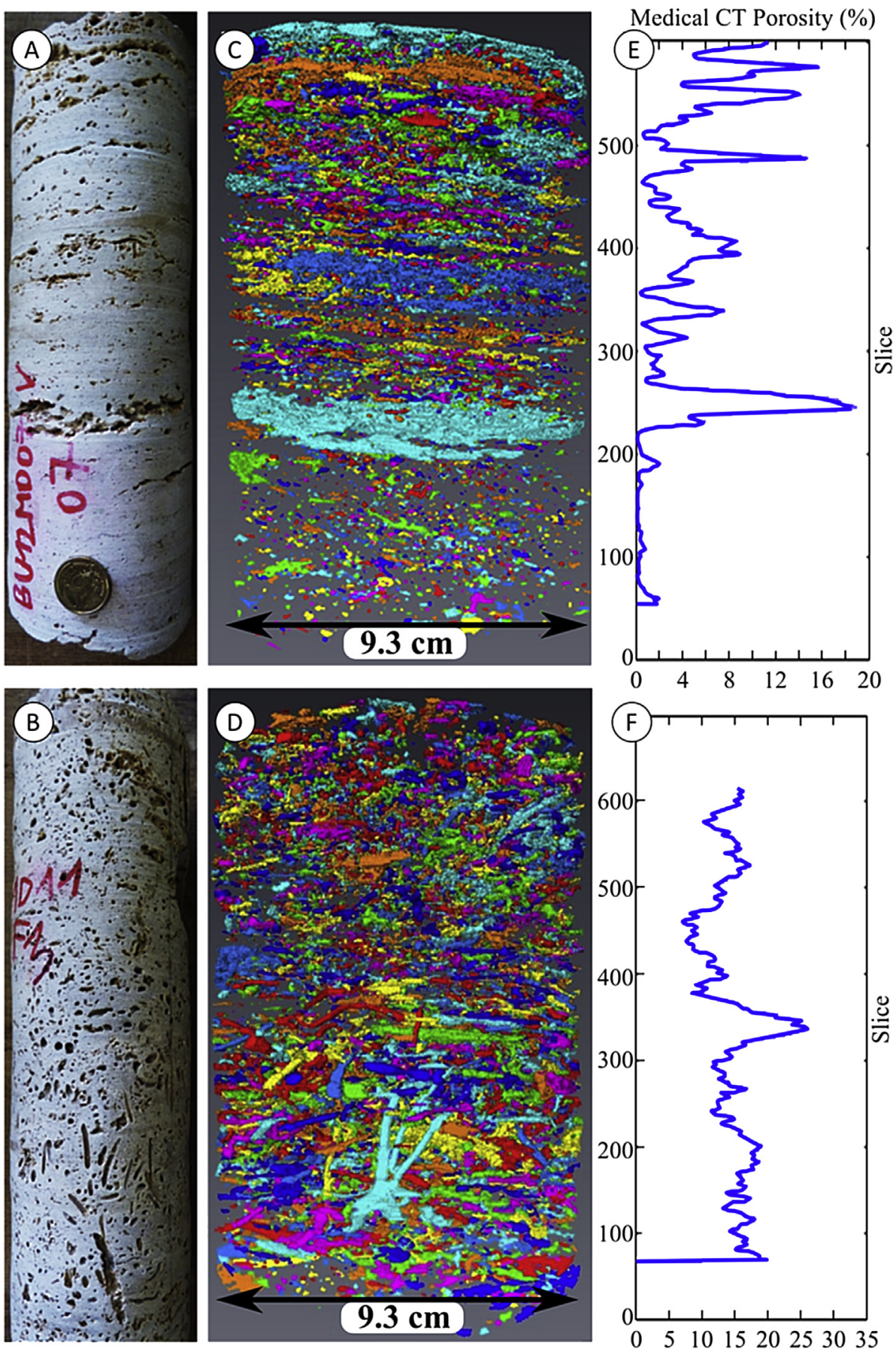

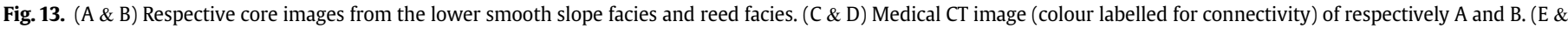
F) Vertical CT-porosity evolution showing heterogeneity along the sample.

et al., 2002; El Desouky et al., 2015). Based on the reported geological setting, the travertine bearing fluids could have interacted with Late Triassic, Eocene and/or to limited extent with Miocene carbonate sequences within the TR (Fig. 1). To the best of our knowledge, no strontium isotope data of these carbonates exist in literature. Therefore, to deduce the parent carbonate source rock of the Budakalász travertines, their ${ }^{87} \mathrm{Sr} /{ }^{86} \mathrm{Sr}$ ratios $(0.70841-0.70844)$ have been compared with the ${ }^{87} \mathrm{Sr} /{ }^{86} \mathrm{Sr}$ ratios of marine carbonate rocks (McArthur and Howarth, 2004). This comparison shows that the values are significantly higher than the ratios of marine carbonates deposited during the Late Triassic (0.7076-0.7080) and
Eocene (0.7077-0.7078) of the TR. They, however, show a good correlation with the $\mathrm{Sr}$ isotopic signatures of Miocene marine carbonates (0.7082-0.78090; McArthur and Howarth, 2004). The porous reef shallow marine Lower Miocene Leitha limestones crop out around Budapest and along the northern margin of the Visegrád Mountains (Nagymarosy and Hámor, 2012). Based on their geographical distance and limited occurrence, they can be considered to be unlikely as sole fluid source rocks, especially considering that they would mix with low ${ }^{87} \mathrm{Sr} /{ }^{86} \mathrm{Sr}$ ratio signature waters from Triassic and Eocene aquifers that surround the study area. This indicates that the precipitation waters interacted with other rock 
(A) A

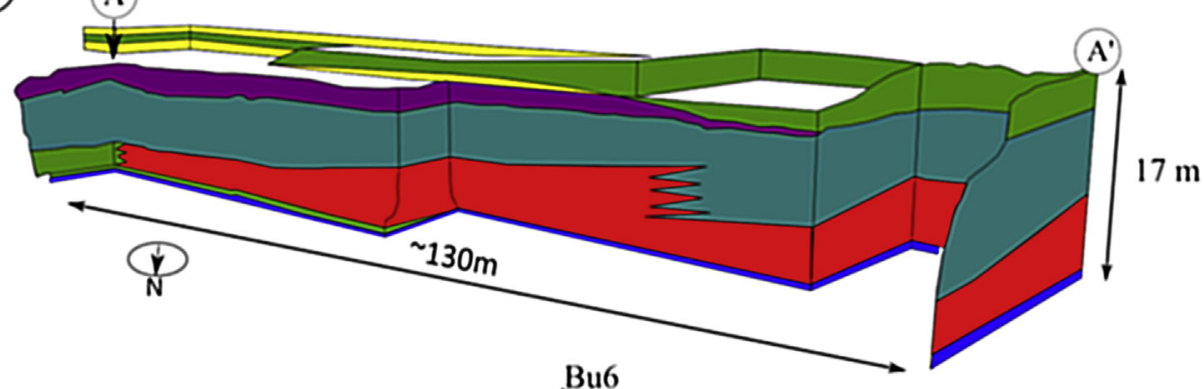

(B)

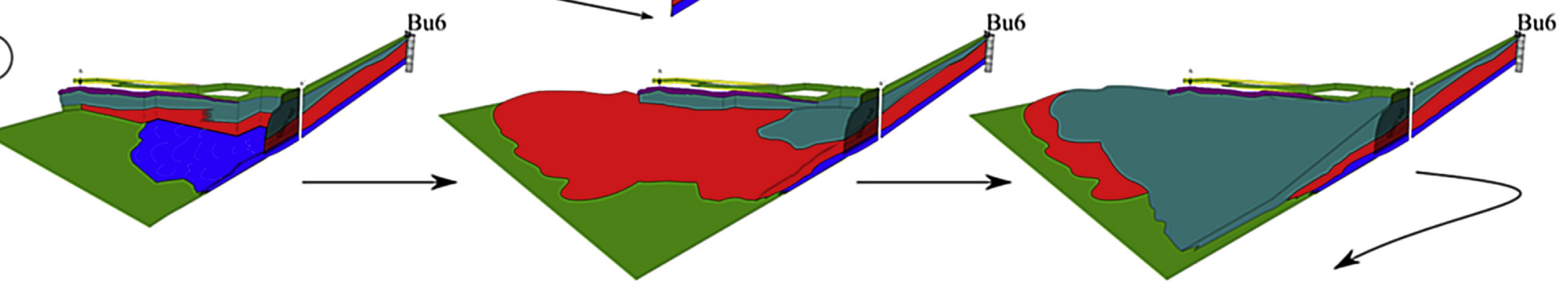

(C)

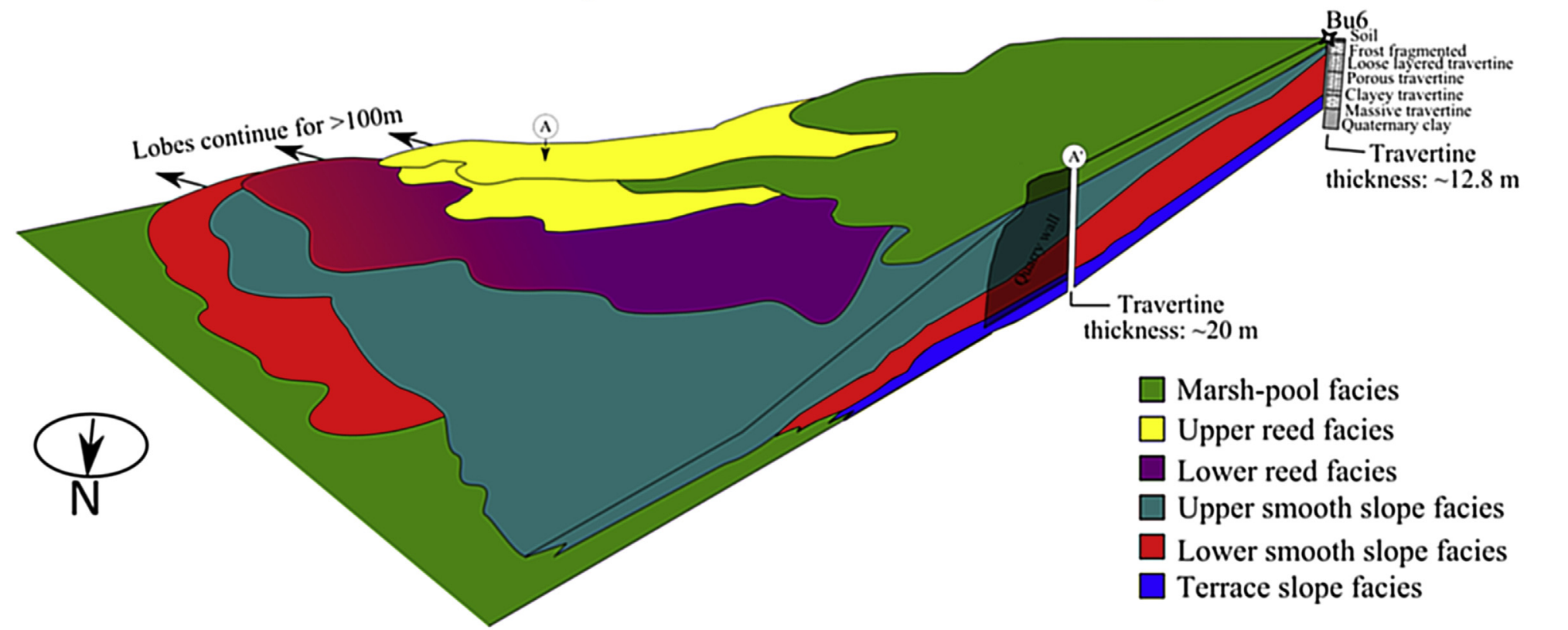

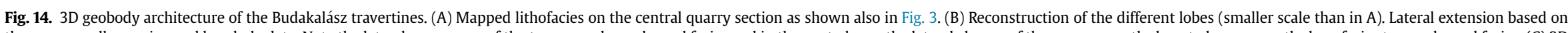

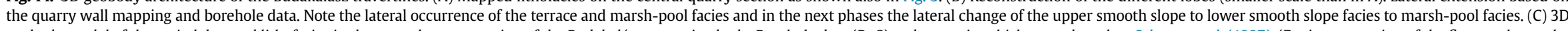

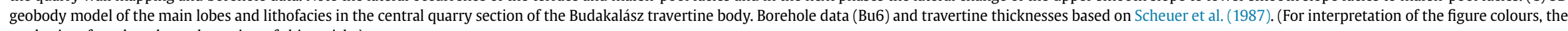
reader is referred to the web version of this article.) 


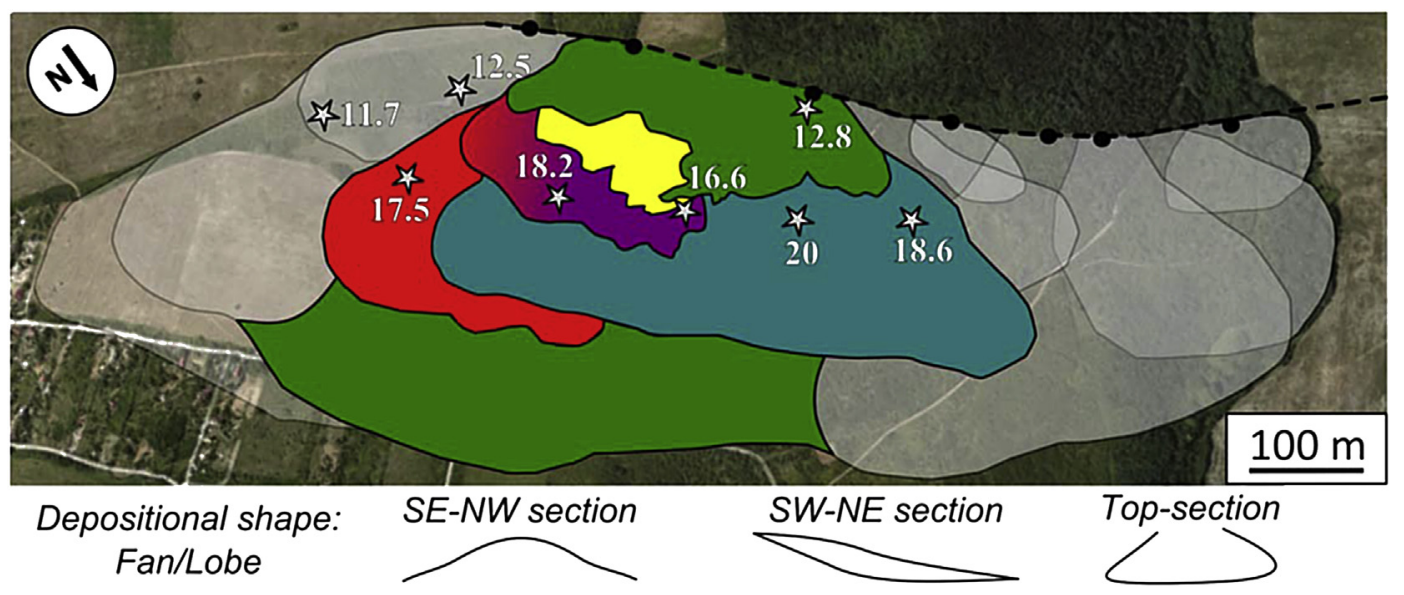

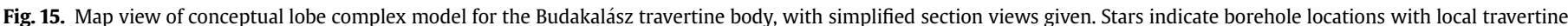

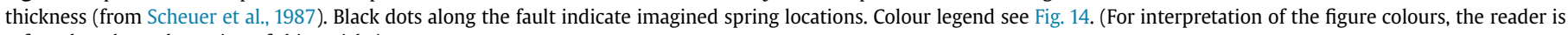
referred to the web version of this article.)

sequences with higher ${ }^{87} \mathrm{Sr} /{ }^{86} \mathrm{Sr}$-ratios. Based on the local geology, the Oligocene siliciclastic sequences that are found in the Budakalász area directly underneath the travertines and on top of the Triassic and Eocene sequences (Scheuer et al., 1987), are a likely candidate. Given the uniform signature, leaching of the high ${ }^{87} \mathrm{Sr} /{ }^{86} \mathrm{Sr}$-ratios from these Oligocene lithologies should have happened during (downwards) percolation of the fluids, in contrast to during fluid rise before travertine precipitation, since that would cause a more variable signature.

\subsection{Stable isotope geochemistry}

The omnipresence of diagenetic fabrics as observed by petrographic analyses raises questions about possible resetting of the stable isotopic signatures, as discussed for other locations by Manfra et al. (1974, 1976), Janssen et al. (1999), Chafetz and Guidry (2003), Andrews and Brasier (2005), Andrews (2006), Rainey and Jones (2007), Brasier et al. (2011), De Filippis et al. (2013) and Claes et al. (2015a). The differences in the order of $1 \%$ for both $\delta^{13} \mathrm{C}$ and $\delta^{18} \mathrm{O}$ between the rock framework and cement samples further stimulate discussion. A similar magnitude of diagenetic shift in stable isotope signature has been observed by Janssen et al. (1999) after comparison of recent and fossil deposits. In addition, with the exception of the sparitic dendritic shrub crusts, that show elevated $\delta^{13} C_{\text {trav }}$ (in line with Kele et al., 2003), no clear relationship with the lithofacies or fabrics is observed. The fact that only these densest samples, in which the fabrics appear the most pristine, i.e. fully sparitic with only micritisation along the edges, are distinct from the general rather uniform isotopic signature is in line with a diagenetic resetting of the general stable isotopic compositions.

Kele et al. (2003) analysed 60 bulk samples with respect to their $\delta^{18} \mathrm{O}$ and $\delta^{13} \mathrm{C}$ signature from 3 distinct vertical sections in the Budakalász travertine, and Földvári et al. (2003) analysed 23 bulk samples from an additional fourth section nearby (Fig. 13). No differentiation was made between rock framework and cement phases. The $\delta^{18} \mathrm{O}$ compositions reported in these analyses range between $-14 \%$ and $-9.4 \%$ (mean $=-11.2 \%$ ), while the $\delta^{13} \mathrm{C}$ signatures range between 0.3 and $2.8 \%$ ( Although, the ranges of these literature isotopic compositions are rather similar to the ranges reported here, most of the bulk sample analyses are systematically enriched in both stable oxygen as well as carbon isotopic signatures (Fig. 12). Given the fact that the samples in these literature studies have been taken more distally from the spring location(s), the relative enrichment in the oxygen and carbon signatures can readily be explained by the effect of degassing and evaporation (e.g. Turi, 1986; Pentecost, 2005), i.e. in line with the geobody architecture. This implies that lateral depositional changes in stable isotope trends have been preserved.

Although the fabrics and stable isotope signatures of the Budakalász travertines thus show indications of diagenetic resetting, their stable isotope signatures might still be diagnostic and preserve earlier overall trends, in line with Andrews and Brasier (2005), Andrews (2006), Rainey and Jones (2007) and Claes et al. (2015a). For carbon this can be explained by the local buffering effect (Brasier et al., 2011). The carbon isotopic signature will result from continuous re-equilibration with new fluids from syndepositional conditions onwards (Brasier et al., 2013). This implies that the order of magnitude of diagenetic resetting can be relatively small and that the extreme values are likely to become less pronounced. The oxygen isotopes are more readily altered during diagenesis, however, if the original temperature and $\delta^{18} \mathrm{O}$ of the precipitating waters remain relatively constant, the travertine isotopic signatures will remain unchanged.

Even taking the $\sim 1 \%$ diagenetic shift into account, an obvious carbon source remains to be found in the Triassic, Eocene and Miocene carbonate sequences, which mainly constitute the Buda Hills (i.e. TR). Several studies (e.g. Scheuer and Schweitzer, 1980; Vitális and Hegyi, 1982) stated that both ancient (i.e. post - Late Pannonian) and present travertine deposits are related to the open karst-hydrodynamic system of the entire TR (Kele et al., 2003). Latest hydrogeological studies (Eröss et al., 2012; Poros et al., 2012; Mádl-Szőnyi and Tóth, 2015) showed that at first the system was confined and changed to unconfined only in the Plio-Pleistocene times. As the catchment area of the thermal springs of the Buda Hills extends to the southwestern parts of the TR, meteoric waters, during their underground circulation, have dissolved the Mesozoic-Cenozoic carbonate rocks and subsequently discharged as hypogenic karst-related thermal springs at the Buda Hills. Their rather high temperature is the result of the above-average geothermal gradient in the Pannonian Basin since Miocene times (Lenkey et al., 2002; Kele et al., 2003). A stable isotopic study of Haas and Demény (2002) provided $\delta^{13} \mathrm{C}$ compositions of Triassic Dachstein Limestone and Main Dolomites between $0.1 \%$ and $3.4 \%$ V-PDB. The fluids source waters passed or mixed with waters from 
these aquifers in the Budakalász region that are situated at a depth of 1000-2000 m (Mádl-Szőnyi et al., 2015). The high geothermal gradient $\left(50-55^{\circ} \mathrm{C} / \mathrm{km}\right)$, explains the minimum temperatures of $60-90{ }^{\circ} \mathrm{C}$ in the aquifers (maximum temperatures $\sim 125^{\circ} \mathrm{C}$ ). Fractionation during thermal decarbonation is temperature dependent. It can range from 4.6 to $6.8 \%$ for a temperature of 90 to $60{ }^{\circ} \mathrm{C}$ respectively (Bottinga, 1968). Based on this, a minimum of $-7 \%$ $\delta^{13} \mathrm{C}_{\mathrm{CO} 2}$ in the water sourced by the deep marine carbonates is obtained. For more shallow aquifers, with lower temperatures $\left(\sim 30{ }^{\circ} \mathrm{C}\right)$, a fractionation up to $-10 \% \delta^{13} \mathrm{C}_{\mathrm{CO} 2}$ in the water can be attained.

The $\delta^{13} C_{\text {trav }}$ signatures of both rock framework and cement phases fall within the ranges given by Pentecost (2005) for both thermogene and meteogene travertines. Based on Teboul et al. (2016), the signatures are typical for hypogean travertines associated with rock sequences of (marine) carbonates and/or igneous rocks (except carbonatites and ultramafics). The $\delta^{13} \mathrm{C}$ of the travertines were recalculated to the $\delta^{13} \mathrm{C}$ of the dissolved inorganic carbon in the fluids based on the equation of Panichi and Tongiorgi (1976). The resulting fluid $\delta^{13} \mathrm{C}$ ranges between -7 and $-11 \%$ VPDB, with a mean value of $-9 \%$ V-PDB. This is perfectly in line with the calculated minimum of $-7 \% \delta^{13} \mathrm{C}_{\mathrm{CO} 2}$ originating from the deep aquifers. Considering, however, that most likely fractionation processes (evaporation, degassing, microbial influence) resulted in increased $\delta^{13} \mathrm{C}_{\text {trav }}$ signatures, additional low $\delta^{13} \mathrm{CCO}_{2}$-sources were also involved or diagenetic resetting with low $\delta^{13} \mathrm{C}_{\mathrm{CO} 2}$ fluids should be considered. This can be caused by mixing with waters from more shallow aquifers. However, this might also be explained by a relatively larger atmosphere- and/or soil-derived $\mathrm{CO}_{2}$ component in the precipitating fluids. The latter also readily explain the negative shift in $\delta^{13} \mathrm{C}$ signatures of the cement phases relative to the rock framework phases.

The $\delta^{18} \mathrm{O}_{\text {trav }}$ signatures show rather uniform values for both rock framework and cement phases (Fig. 9). They are relatively negative ( -13 to $-10.4 \% \mathrm{~V}-\mathrm{PDB}$ ), possibly related to relatively high temperatures or more likely relates to the low initial $\delta^{18} \mathrm{O}_{\text {water }}$. Negative oxygen isotopic values were reported for geothermal ( -14 to $-11 \%$ V-SMOW) and infiltration waters $(-10$ to $-9 \%$ V-SMOW) in the Buda Hills (Babidorics et al., 1998). According to Kele (2009) meteoric waters during warmer periods in the Pleistocene (i.e. interstadials) likely had $\delta^{18} \mathrm{O}$ values of $-12 \pm 1 \%$ V-SMOW, which is slightly lower than the assumed signatures of Holocene waters. Using this Pleistocene value, the temperatures of the travertine precipitating fluids at Budakalász were calculated (range between 15 and $31{ }^{\circ} \mathrm{C}$ ) based on the empirical equation of Kele et al. (2015), which was developed for vent and pool travertines and tufa carbonates. For downstream carbonates the vent-based equation will thus possibly overestimate the temperature of travertine precipitation. Based on textural evidences and the general geobody architecture none of the sampling locations precipitated close to the discharge point(s). Considering that rock framework samples represent more than one micro-fabric and the possibility of isotopic resetting, the oxygen isotopic composition from Late-Pleistocene and Holocene waters ( -14 to $-9 \%$ SMOW) should be taken into account. In this case, the overall fluid temperatures were ambient to slightly superambient, i.e. in the range of $10-50{ }^{\circ} \mathrm{C}$, based on the most extreme values. The positive shifts of the mean oxygen isotopic signatures $(+0.5 \%)$ of the cement phases is likely related to the precipitation from a fluid with a lower temperature or to a change in the original oxygen isotopic signature of the fluid. The observed opposite trends for some of the lower smooth slope facies combined with the higher $\delta^{13} \mathrm{C}_{\text {trav }}$ may reflect precipitation from a relatively hotter fluid, likely resulting from sub-surface percolation during on-going travertine precipitation.

\subsection{Petrophysical properties}

The reported wide ranges for porosity (5-27\%) and permeability ( 0 to $>25,000 \mathrm{mD}$ ) are caused by the heterogeneous nature of the travertines, with the alternation of porous and tight laminae and beds at millimetre- to centimetre-scale (clearly visible in medical CT, Fig. 13). The relation to the lamination/bedding is very pronounced in the porosity-permeability plot. Unless the whole core plug is taken in a dense bed, horizontal core plug permeabilities are much higher than the vertical ones in which along the flow direction dense layers block the flow. This observation is most pronounced for the terrace and smooth slope facies. Although the porosity-permeability characteristics of the lithofacies are not statistically different, with exception of the upper reed facies, a clear relation to the lithofacies exists (Fig. 12). The marsh-pool facies for example has a more homogeneous fabric and porosity network, which is reflected by smaller ranges of the porosity-permeability results. The high permeabilities of the reed facies can be explained by the occurrence of plant moulds oriented along the core plug. It should be considered, however, that on larger scale the moulds form separate pores and thus the overall large-scale permeability of the facies will be lower. The field-observed differences in porosity between the lower and upper smooth slope facies are most pronounced in the horizontal core plugs, but even more in the field in the form of cavities. In general it can be concluded that the increase in slope and the occurrence of plants result in higher porosity-permeability values, as observed in the Ballı travertines (Soete et al., 2015). In the Budakalász travertine for example, for the lower smooth slope compared to the upper smooth slope facies, a difference of less than $5^{\circ}$ in slope is associated with an increase of more than $2 \%$ in porosity The main porosity types and porositypermeability characteristics remain related to the depositional framework, which also control the amount of pore reduction by cementation and pore enlargement by local dissolution. From an exploration point of view, it is important to interpret these properties in terms of preferential flow paths. Flow through the travertine body will follow lamination to bedding and consequently also the lobe morphologies, emphasising the importance of understanding the geobody architecture. The highest porosity volumes are expected in the reed facies. Despite the negative effect of cementation, however, the porosity-permeability characteristics of all the encountered Budakalász facies are representative for good reservoir qualities (e.g. Levorsen, 1954). It should be noted that for the presented porosity-permeability evaluation, large-scale pores, like cavities and the fracture networks, which are larger than the examined core plugs, have not been included. While the encountered cavities could significantly increase overall porosity, their effect on large scale permeability will be limited. Although the fracture network based on preliminary field evaluation is limited compared to other locations (e.g. the Ballık travertine, Turkey, Van Noten et al., 2013; the Acquasanta travertine, Maggi et al., 2015), it could have a major impact and it should be the focus of future research.

\section{Conclusion}

The presented geobody model provides a unique insight into the complex kilometre-scale three-dimensional geobody architecture of lobe complex travertines. The Budakalász travertines are formed by several heterogeneous terrace and smooth sloping travertine lobes that laterally and vertically evolve into reed and marsh-pool facies. These four main lithofacies have been distinguished with proximal and distal equivalents. Overall the system evolved from a terrace system to a palustrine environment and was temporarily interrupted by exposure. Subsequently, several gradually 
steepening smooth slope travertine lobes formed. With time, plants were able to colonise the slopes and were encrusted as evidenced by the macrophyte facies. Finally, the system declined and ceased completely as attested by the upper lacustrine to palustrine carbonate mud facies. The cessation of the system can be related to the tectonic uplift of the Buda Hills.

The ${ }^{87} \mathrm{Sr} /{ }^{86} \mathrm{Sr}$ ratios of the continental carbonate samples indicate interaction of travertine precipitating fluids with (Oligocene) siliciclastic sequences besides the Late Triassic, Eocene and/or Miocene carbonate sequences.

The petrographic characteristics together with the general uniform $\delta^{18} \mathrm{O}$ and $\delta^{13} \mathrm{C}$ signatures, and the difference between rock framework and cement stable isotope signatures point out the influence of diagenesis on the stable isotopic compositions of the travertines. The relatively high $\delta^{13} \mathrm{C}$ in combination with the preserved sparitic fabrics of sparitic dendritic crusts, point to their pristine nature in contrast to the general uniform signature of the other facies. Despite the influence of diagenesis, depositional trends are preserved and isotope signatures can still be diagnostic. The $\delta^{13} \mathrm{C}$ signatures are typical for hypogean travertines and indicate that the $\mathrm{CO}_{2}$ is obtained from marine rocks of the karstic reservoir mixed with most likely atmospheric and/or soil $\mathrm{CO}_{2}$. The $\delta^{18} \mathrm{O}$ signatures suggest that the overall temperatures of the travertine precipitating fluids were ambient to slightly super-ambient $\left(<50{ }^{\circ} \mathrm{C}\right)$.

Porosity values range between 5.2 and $27 \%$ (with a mean value of $13.7 \%$ ). Empirical Klinkenberg permeability values are strongly direction dependent, related to layer-associated anisotropies. The higher values for the latter clearly link to the many layer parallel oriented pores encountered in most lithofacies, except for the marsh-pool facies. Secondary dissolution of the Budakalász travertines is minor, likely due to the quick saturation of infiltrating water. Despite the negative effect of cementation, the porositypermeability characteristics of the encountered facies are representative for good reservoir qualities. Increases in slope and the occurrence of plants result in higher porosity-permeability characteristics. Fluid flow within such a reservoir will be mainly parallel to the lamination and bedding, emphasising the importance of understanding the geobody architecture.

The reconstruction of the $3 \mathrm{D}$ geobody architecture of the Budakalász lobe complex coupled to its geochemical and petrophysical properties provides a unique dataset that so far was lacking from literature and 3D reservoir modelling databases.

\section{Acknowledgement}

Thanks go to the Budakalász quarry owner and workers. We thank Herman Nijs (Leuven, Belgium) who prepared the thinsections. Moreover, Prof. M. Joachimsky is acknowledged for supervising the stable $\mathrm{C}$ - \& $\mathrm{O}$-isotope analyses carried out at the University of Erlangen (Germany). M. M. Erthal is thanked for discussions on the petrography. This study is complimentary to a Joint Industry Project (supported by a consortium of oil companies, i.e. Petrobras, TOTAL and Eni E\&P) studying travertines in Turkey. The Royal Flemish Academy of Belgium of Science and Art as well as the Hungarian Academy of Sciences are thanked for their support in the framework of bilateral agreements. S. Kele received support by the János Bolyai research scholarship of the Hungarian Academy of Sciences and the Hungarian National Research Fund (OTKA 101664). The manuscript improved significantly thanks to the careful critical input of the reviewers and editors.

\section{Appendix A. Supplementary data}

Supplementary data related to this article can be found at http:// dx.doi.org/10.1016/j.quaint.2016.09.007.

\section{References}

Andrews, J.E., 2006. Palaeoclimatic records from stable isotopes in riverine tufas: synthesis and review. Earth-Science Reviews 75, 85-104.

Andrews, J.E., Brasier, A.T., 2005. Seasonal records of climatic change in annually laminated tufas: short review and future prospects. Journal of Quaternary Science 20, 411-421.

Arenas, C. Vázquez-Urbez, M., Auqué, L., Sancho, C., Osácar, C., Pardo, G., 2014 Intrinsic and extrinsic controls of spatial and temporal variations in modern fluvial tufa sedimentation: a thirteen-year record from a semi-arid environment. Sedimentology 61, 90-132.

Arp, G., Wedemeyer, N., Reitner, J., 2001. Fluvial tufa formation in a hard-water creek (Deinschwanger Bach, Franconian Alb, Germany). Facies 44, 1-22.

Arpási, M., Lorberer, A., Pap, S., 2000. High pressure and temperature (geopressured) geothermal reservoirs in Hungary. In: Proceedings World Geothermal Congress 2000, Kyushu-Tohoku, Japan, May 28-June 10, 2000.

Babidorics, J., Fórizs, I., Papp, S., 1998. Isotope hydrogeological study of the thermal karst system in the Buda Mountains, Hungary. RMZ-Materials and Geoenvironment 45/1-2, 8-12.

Balcaen, L., De Schrijver, I., Monens, L., Vanhaecke, F., 2005. Determination of the ${ }^{87} \mathrm{Sr} /{ }^{86} \mathrm{Sr}$ isotope ratio in USGS silicate reference materials by multi-collector ICP-mass spectrometry. International Journal of Mass Spectrometry 242, $251-255$.

Báldi, T., Nagymarosy, A., 1976. Silicification of the Hárshegy Sandstone and its hydrothermal origin. Bulletin of the Hungarian Geological Society 106, 257-275 (In Hungarian).

Beasley, C.J., Fiduk, J.C., Bize, E., Boyd, A., Frydman, M., Zerilli, A., Dribus, J.R. Moreira, J.L.P., Capeleiro Pinto, A.C., 2010. Brazil's Presalt Play, oilfield review. Autumn 2010 (22), 3.

Bottinga, Y., 1968. Calculation of fractionation factors for carbon and oxygen isotopic exchange in the system calcite-carbon dioxide-water. Journal of Physical Chemistry $72,800-808$.

Brasier, A.T., 2011. Searching for travertines, calcretes and speleothems in deep time: processes, appearances, predictions and the impact of plants. Earth-Science Reviews 104, 213-239.

Brasier, A.T., Andrews, J.E., Kendall, A.C., 2011. Diagenesis or dire genesis? The origin of columnar spar in tufa stromatolites of Central Greece and the role of chironomid larvae Sedimentology 58, 1283-1302.

Brasier, A.T., Salminen, P.E., Melezhik, V.A., Fallick, A.E., 2013. Earth's earliest travertines, chapter 7.9 terrestrial environments. In: Melezhik, et al. (Eds.), Reading the Archive of Earth's Oxygenation, Global Events and the Fennoscandian Arctic Russia - Drilling Early Earth Project, vol. 3. Springer Verlag, Berlin Heidelberg. http://dx.doi.org/10.1007/978-3-642-29670-3 9.

Brasier, A.T., Rogerson, M.R., Mercedes-Martin, R., Vonhof, H.B., Reijmer, J.J.G., 2015 A test of biogenicity criteria established for microfossils and stromatolites on Quaternary tufa and speleothem materials formed in the "Twilight Zone" at Caerwys, U.K. Astrobiology 15 (10), 883-900.

Capezzuoli, E., Gandin, A., Pedley, M., 2014. Decoding tufa and travertine (fresh water carbonates) in the sedimentary record: the state of the art. Sedimentology $61,1-21$

Chafetz, H.S., 2013. Porosity in bacterially induced carbonates: focus on micropores AAPG Bulletin 97 (11), 2103-2111.

Chafetz, H.S., Folk, R.L., 1984. Travertines: depositional morphology and bacterial constructed constituents. Journal of Sedimentary Petrology 54/1 0289-0316.

Chafetz, H.S., Guidry, S.A., 1999. Bacterial shrubs, crystal shrubs, and ray-crystal shrubs: bacterial vs, abiotic precipitation. Sedimentary Geology 126, 57-74.

Chafetz, H.S., Guidry, S.A., 2003. Deposition and diagenesis of Mammoth hot springs travertine, Yellowstone National Park, Wyoming, U.S.A. Canadian Journal of Earth Sciences 40, 1515-1529. http://dx.doi.org/10.1139/E03-051.

Chafetz, H.S., Srdoc, D., Horvatincic, N., 1994. Early diagenesis of Plitvice lakes waterfall and barrier travertine deposits. Géographie physique et Quaternaire 48 (3), 247-255.

Claes, H., Soete, J., Van Noten, K., El Desouky, H., Marques Erthal, M., Vanhaecke, F., Özkul, M., Swennen, R., 2015a. Sedimentology, three-dimensional geobody reconstruction and carbon dioxide origin of Pleistocene travertine deposits in the Ballık area (south-west Turkey). Sedimentology 62 (5), 1408-1445.

Claes, S., Soete, J., Cnudde, V., Swennen, R., 2015b. A 3D Classification for Mathematical Pore Shape Description in Complex Carbonate Reservoir Rocks: Mathematical Geosciences.

Croci, A., Della Porta, G., Capezzuoli, E., 2016. Depositional architecture of a mixed travertine-terrigenous system in a fault-controlled continental extensional basin (Messinian, Southern Tuscany, Central Italy). Sedimentary Geology 332 13-39.

Crossey, L.J., Fischer, T.P., Patchett, P.J., Karlstrom, K.E., Hilton, D.R., Newell, D.L., Huntoon, P., Reynolds, A.C., de Leeuw, G.A.M., 2006. Dissected hydrologic system at the Grand Canyon: interaction between deeply derived fluids and plateay aquifer waters in modern springs and travertine. Geological Society of America. Geology 34 (1), 25-28. http://dx.doi.org/10.1130/G22057.1.

De Boever, E., Foubert, A., Oligschlaeger, D., Claes, S., Soete, J., Bertier, P., Özkul, M. Virgone, A., Swennen, R., 2016. Multiscale approach to (micro)porosity quantification in continental spring carbonate facies: case study from the Cakmak quarry (Denizli, Turkey). Geochemistry, Geophysics, Geosystems. http:// dx.doi.org/10.1002/2016GC006382. 
De Filippis, L., Facenna, C., Billi, A., Anzalone, E., Brilli, M., Soligo, M., Tuccimei, P. 2013. Plateau versus fissure ridge travertine from Quaternary geotherma springs of Italy and Turkey: interactions and feedbacks between fluid discharge, palaeoclimate, and tectonics. Earth-Science Reviews 123, 35-52.

De Muynck, D., Huelga-Suarez, G., Van Heghe, L., Degryse, P., Vanhaecke, F., 2009. Systematic evaluation of a strontium-specific extraction chromatographic resin for obtaining a purified $\mathrm{Sr}$ fraction with quantitative recovery from complex and Ca-rich matrices. Journal of Analytical Atomic Spectrometry 24, 1498-1510.

Della Porta, G., 2015. Carbonate build-ups in lacustrine, hydrothermal and fluvia settings: comparing depositional geometry, fabric types and geochemical signature. In: Bosence, D.W.J., Gibbons, K.A., Le Heron, D.P., Morgan, W.A. Pritchard, T., Vining, B.A. (Eds.), Microbial Carbonates in Space and Time: Implications for Global Exploration and Production, Geological Society, vol. 418. Special Publications, London, pp. 17-68. http://dx.doi.org/10.1144/SP418.4.

El Desouky, H., Soete, J., Claes, H., Özkul, M., Vanhaecke, F., Swennen, R., 2015. Novel applications of fluid inclusions and isotope geochemistry in unravelling the genesis of fossil travertine systems. Sedimentology 62, 27-56.

Erőss, A., Mádl-Szőnyi, J., Surbeck, H., Horváth, Á., Goldscheider, N., Csoma, A.É. 2012. Radionuclides as natural tracers for the characterization of fluids regiona discharge areas, Buda Thermal Karst, Hungary. Journal of Hydrology 426 124-137.

Fodor, L., Magyari, A., Fogarasi, A., Palotás, K., 1994. Tertiary tectonics and late Palaeogene sedimentation in the Buda Hills, Hungary. A new interpretation of the Buda line. Földt Közlöny 124, 129-305.

Földvári, M., Paulik, F., Paulik, J., 1988. Possibility of thermal analysis of different types of bonding of water in minerals. Journal of Thermal Analysis 33 (1) $121-132$.

Földvári, M., Berner, Zs, Stüben, D., 2003. Thermoanalytical study of Quaternary thermal lacustrine travertine occurrences in Hungary (Buda-Vár-hegy, Budakalász, Szomód-Les-hegy). Acta Geologica Hungarica 46 (2), 195-204.

Ford, T.D., Pedley, H.M., 1996. A review of tufa and travertine deposits of the world, Earth Science Reviews 41, 3-4, 117-175.

Fouke, B.W., 2011. Hot-spring systems geobiology: abiotic and biotic influences on travertine formation at Mammoth Hot Springs, Yellowstone National Park, USA. Sedimentology 58, 170-219.

Fouke, B.W., Farmer, J.D., Des Marais, D.D., Pratt, L., Sturchio, N.C., Burns, P.C. Discipulo, M.K., 2000. Depositional facies and aqueous-solid geochemistry of travertine-depositing hot springs (Angel terrace, Mammoth hot springs, Yellowstone National Park, U.S.A.). Journal of Sedimentary Research 70, 565-585.

Freytet, P., Verrecchia, E.P., 1999. Calcitic radial palisadic fabric in freshwater stromatolites: diagenetic and recrystallized feature or physicochemical sinte crust? Sedimentary Geology 126, 97-102.

Freytet, P., Verrecchia, E.P., 2002. Lacustrine and palustrine carbonate petrography: an overview. Journal of Paleolimnology 27 (2), 221-237.

Gandin, A., Capezzuoli, E., 2008. Travertine versus calcareous tufa: distinctive petrologic features and stable isotopes signatures. Italian journal of Quaternary Sciences 21 (1B), 125-136.

Gandin, A., Capezzuoli, E. 2014. Travertine: distinctive depositional fabrics of carbonates from thermal spring systems. Sedimentology 61 (1), 264-290.

Goldscheider, N., Mádl-Szőnyi, J., Erőss, A., Schill, E., 2010. Review: therma water resources in carbonate rock aquifers. Hydrogeology Journal 18/6, 1303-1318.

Golubic, S., Violante, C., Plenkovic-Moraj, A., Grgasovic, T., 2008. Travertines and calcareous tufa deposits: an insight into diagenesis. Geologia Croatia 61, 2-3, 363-378.

Gradzinski, M., Wroblewski, W., Dulinski, M., Hercman, H., 2014. Earthquakeaffected development of a travertine ridge. Sedimentology 61, 238-263.

Guo, L., Riding, R., 1994. Origin and diagenesis of Quaternary travertine shrub fabrics, Rapolano Terme, central Italy. Sedimentology 41, 499-520.

Guo, L., Riding, R., 1998. Hot-spring travertine facies and sequences, late Pleistocene Rapolano Terme, Italy. Sedimentology 45 (1), 163-180.

Györi, O., Poros, Zs, Mindszenty, A., Molnár, F., Fodor, L., Szabó, R., 2011. Diagenetic history of Paleogene carbonates, Buda Hills, Hungary. Bulletin of the Hungarian Geological Society 141 (4), 341-361 (in Hungarian with English abstract).

Haas, J., Demény, A., 2002. Early dolomitisation of late Triassic platform carbonates in the Transdanubian Range (Hungary). Sedimentary Geology 151, $225-242$.

Haas, J., Hámor, G., Jámbor, Kovács, S., Nagymarosy, A., Szederkényi, T., 2001. Geology of Hungary. Eötvös University Press, Budapest.

Huerta, P., Armenteros, I., Tomé, O.M., Gonzalvez, P.R., Silva, P.G., GonzalezAguilera, D., Carrasco-Garcia, P., 2016. 3-D modelling of a fossil tufa outcrop. The example of La Pena del Manto (Soria, Spain). Sedimentary Geology 333, $130-146$

Jamtveit, B., Hammer, Ø., Andersson, C., Dysthe, D.K., Heldmann, J., Fogel, M.L., 2006 Travertines from the troll thermal springs, Svalbard. Norwegian Journal of Geology 387-395.

Janssen, A., Swennen, R., Podoor, N., Keppens, E., 1999. Biological and diagenetic influence in recent and fossil tufa from Belgium. Sedimentary Geology 126, $74-95$

Jung, A., Aigner, T., 2012. Carbonate geobodies: hierarchical classification and database - a new workflow for 3D reservoir modelling. Journal of Petroleum Geology 35 (1), 49-66.

Kahle, C.F. 1977. Origin of subaerial Holocene calcareous crusts: role of algae, fung and sparmicritization. Sedimentology 24, 413-435.
Karátson, D., Németh, K., Székely, B., Ruszkiczay-Rüdiger, Zs, Pécskay, Z., 2006. ncision of a river curvature due to exhumed Miocene volcanic landforms: Danube Bend, Hungary. International Journal of Earth Sciences 95 (5), 929-944.

Karátson, D., Oláh, I., Pécskay, Z., Márton, E., Sz, Harangi, Dulai, A., Zelenka, T., 2007. Miocene volcanism in the Visegrád Mountains (Hungary): an integrated approach to regional volcanic stratigraphy. Geologica Carpathica 58 (6), $541-563$.

Kele, S., 2009. Investigations on Freshwater Limestones from the Carpathian-Basin: Palaeoclimatological and Sedimentological Studies (PhD thesis). Eötvös Loránd University, Budapest (Hungary), p. 176.

Kele, S., Vaselli, O., Szabó, C., Minissale, A., 2003. Stable isotope geochemistry of Pleistocene travertine from Budakalász (Buda Mts, Hungary). Acta Geologica Hungarica 46 (2), 161-175.

Kele, S., Özkul, M., Fórizs, I., Gökgöz, A., Baykara, M.O., Alçiçek, M.C., 2011. Stable isotope geochemical study of Pamukkale travertines: new evidences of lowtemperature non-equilibrium calcite-water fractionation. Sedimentary Geology $238,191-212$

Kele, S., Bernasconi, S.M., Kluge, T., John, M.C., Capezzuoli, E., Millan, I.M., Meckler, N.M., Ziegler, M., Breitenbach, S.F.M., Deák, J., Hanselmann, K., Yan, H. Liu, Z., 2015. Calibration of the conventional carbonate-water and the "clumped isotope' thermometer on travertines and tufas in the $5-95{ }^{\circ} \mathrm{C}$ temperature range. Geochimica et Cosmochimica Acta 168, 172-192.

Kovács, J., Müller, P., 1980. Budai-hegyek hévizes tevékenységének kialakulása és nyomai (Thermal Water-activity and its Traces in the Buda Hills), pp. 93-98. Karszt és Barlang, II. Füzet.

Lebatard, A.E., Alçicçek, M.C., Rochette, P., Khatib, S., Vialet, A., Boulbes, N., Bourl es, D.L., Demory, F., Guipert, G., Mayda, S., Titov, V.V., Vidal, L., de Lumley, H., 2014. Dating the Homo erectus bearing travertine from Kocabas (Denizli, Turkey) at at least $1.1 \mathrm{Ma}$. Earth and Planetary Science Letters 390, 8-18.

Lenkey, L., Dövényi, P., Horváth, F., Cloetingh, S.A.P.L., 2002. Geothermics of the Pannonian basin and its bearing on the neotectonics. EGU Stephan Mueller Special Publication Series 3, 29-40.

Levorsen, A.I., 1954. Geology of Petroleum. W. H. Freeman and Company, San Francisco, p. 703.

Love, K.M., Chafetz, H.S., 1988. Diagenesis of laminated travertine crusts, Arbuckle Mountains, Oklahoma. Journal of Sedimentary Petrology 58, 441-445.

Lucia, F.J., 1983. Petrophysical parameters estimated visual descriptions of carbonate rocks: a field classification of carbonate pore space. Journal of Petroleum Technology. 35 (03), 629-629.

Mádl-Szőnyi, J., Tóth, A., 2015. Basin-scale conceptual groundwater flow model for an unconfined and confined thick carbonate region. Hydrogeology Journal 23, 1359-1380.

Mádl-Szőnyi, J., Pulay, E., Tóth, Á., Bodor, P., 2015. Regional underpressure: a factor of uncertainty in the geothermal exploration of deep carbnoates, Gödöllő Region, Hungary. Environmental Earth Sciences 74 (12), 7523-7538.

Maggi, M., Cianfarra, P., Salvini, F., Coelho de Lima, C., 2015. Staircase fractures in microbialites and the role of lamination-related mechanical anisotropy: the example of the Acquasanta Terme travertine deposits (central Italy). The Geological Society of America Bulletin. http://dx.doi.org/10.1130/B31163.1.

Manfra, L., Masi, U., Turi, B., 1974. Effetti isotopici nella diagenesi dei travertini. Geologica Romana 13, 147-155.

Manfra, L., Masi, U., Turi, B., 1976. La composizione isotopica dei travertini del Lazio. Geologica Romana 15, 127-174.

McArthur, J.M., Howarth, R.J., 2004. Sr-isotope stratigraphy: the Phanerozoic 87Sr 86Sr-curve and explanatory notes. In: Gradstein, F., Ogg, J.G., Smith, A.G. (Eds.), A Geological Timescale. Cambridge University press, Mouscron, pp. 96-105.

Minissale, A., Kerrick, D.M., Magro, G., Murrell, M.T., Paladini, M., Rihs, S., Sturchio, N.C., Tassi, F., Vaselli, O., 2002. Geochemistry of Quaternary travertines in the region north of Rome (Italy): structural, hydrologic and paleoclimatologic implications. Earth Planetary Science Letters 203, 709-728.

Nádor, A., 1991. A Budai-hegység palaeokarszt jelenségei és fejlôdéstörténetük (PhD thesis). Eötvös Lóránd University, Budapest, p. 171.

Nádor, A., 1993. Palaeokarsts and long-term karst evolution of the Buda Mountains, Hungary. Bulletin de la Société géographique de Liège 29, 139-143.

Nagymarosy, A. Hámor, G. 2012. Genesis and evolution of the Pannonian basin. In: Haas, J. (Ed.), Geology of Hungary. Springer Verlag, Berlin Heidelberg, pp. 149-200.

Nicoll, K., Giegengack, R., Kleindienst, M., 1999. Petrogenesis of Artifact-Bearing fossil spring tufa deposits from Kharga Oasis. Egyptian Geoarchaeology 14 (8), 849-863.

Özkul, M., Varol, B., Alçiçek, M.C., 2002. Depositional environments and petrography of Denizli travertines. Bulletin of the Mineral Research and Exploration $125,13-29$.

Panichi, C.E., Tongiorgi, E., 1976. Carbon isotopic composition of $\mathrm{CO}_{2}$ from springs, fumaroles, mofettes and travertines of central and southern Italy: a preliminary prospection method of geothermal areas. In: Proc. 2nd UN Symposium on the Development and Use of Geothermal Energy, San Francisco, 20-29 May 1975 pp. 815-825.

Pazonyi, P., Kordos, L., Magyari, E., Marinova, E., Füköh, L., Venczel, M., 2014. Pleistocene vertebrate faunas of the Süttö travertine complex (Hungary). Quaternary International 319, 50-63.

Pécsi, M., 1973. A vértesszőllösi ópaleolit ősember telephelyének geomorfológiai helyzete és abszolútkora (Geomorphological position and absolute age of the lower Paleolithic site at Vértesszőllős, Hungary). Bulletin of the Hungarian Geological Society 21, 109-125 (In Hungarian). 
Pedley, H.M., 1990. Classification and environmental models of cool freshwater tufas. Sedimentary Geology 68, 143-154.

Pedley, M., 2009. Tufas and travertines of the Mediterranean region: a testing ground for freshwater carbonate concepts and developments. Sedimentology 56, 221-246.

Pedley, M., Rogerson, M., 2010. Introduction to Tufas and Speleothems, Geological Society, vol. 336. Special Publications, London, pp. 1-5.

Pentecost, A., 2005. Travertine, Geologist Association. Springer-Verlag, Berlin, p. 445.

Pola, M., Gandin, A., Tuccimei, P., Soligo, M., Deiana, R., Fabbri, P., Zampieri, D., 2014 A multidisciplinary approach to understanding carbonate deposition under tectonically controlled hydrothermal circulation: a case study from a recent travertine mound in the Euganean hydrothermal system, northern Italy. Sedimentology 61, 172-199.

Poros, Z., Mindszenty, A., Molnár, F., Pironon, J., Győri, O., Ronchi, P., Szekeres, Z., 2012. Imprints of hydrocarbon-bearing basinal fluids on a karst system: mineralogical and fluid inclusion studies from the Buda Hills, Hungary. International Journal of Earth Sciences (Geologische Rundschau) 101, 429-452.

Rainey, D.K., Jones, B., 2007. Rapid cold water formation and recrystallisation of relict bryophyte tufa at the Fall Creek cold springs, Alberta, Canada. Canadian Journal of Earth Sciences 44, 889-909. http://dx.doi.org/10.1139/E07-008.

Rainey, D.K., Jones, B., 2009. Abiotic versus biotic controls on the development of the Fairmont hot springs carbonate deposit, British Columbia, Canada. Sedimentology 56, 1832-1857.

Ronchi, P., Cruciani, F., 2015. Continental carbonates as a hydrocarbon reservoir, an analog case study from the travertine of Saturnia, Italy. AAPG Bulletin 99 (4), $711-734$.

Ruszkiczay-Rüdiger, Zs, Fodor, L., Bada, G., Leél-Össy, Sz, Horváth, E., Dunai, T.J., 2005. Quantification of Quaternary vertical movements in the central Pannonian Basin: a review of chronologic data along the Danube river, Hungary. Tectonophysics 410, 1-4, 157-172.

Scheuer, Gy, Schweitzer, F., 1974. Új szempontok a Budai-Hegység Környéki édesvízi mészköösszeletek képzödéséhez. Föld. Közl. Bulletin of the Hungarian Geological Society 113-134 (In Hungarian).

Scheuer, Gy, Schweitzer, F., 1980. A budai hévízforrások fejlődéstörténete a felsőpannontól napjainkig (Evolution of the Buda thermal springs from the Late Pannonian to nowadays). Hidrológiai Közlöny 11, 492-501 (In Hungarian).

Scheuer, Gy, Schweitzer, F., 1985. Types and forms of travertine cones. Bulletin of the Hungarian Geological Society 115, 385-398 (In Hungarian).

Scheuer, Gy, Schweitzer, F., 1988. Freshwater limestones of the Gerecse and Buda Hills. In: Földrajzi Tanulmányok, 20. Akadémiai Kiadó, Budapest, p. 131 (In Hungarian).

Scheuer, Gy, Schweitzer, F., Szlabóczky, P., 1987. A budakalászi forrásvizi mészkőelöfordulás mérnökgeológiai vizsgálata (Engineer-geological study of the Budakalász travertine). Építőanyag 39, 102-107 (In Hungarian).

Shukla, U.K., Kotlia, B.S., Mathur, P.D., 2002. Sedimentation pattern in a transHimalayan Quaternary lake at Lamayuru (Ladakh), India. Sedimentary Geology $148,3-4,405-424$.
Sierralta, M., Kele, S., Melcher, F., Hambach, U., Reinders, J., van Geldern, R., Frechen, M., 2010. Characterisation and uranium-series dating of travertine from Süttő in Hungary. Quaternary International 222, 178-193.

Soete, J., Kleipool, L.M., Claes, H., Claes, S., Hamaekers, H., Kele, S., Özkul, M., Foubert, A., Reijmer, J.J.G., Swennen, R., 2015. Acoustic properties in travertines and their relation to porosity and pore types. Marine and Petroleum Geology $320-335$.

Steiger, R.H., Jager, E., 1977. Subcomission on geochronology: convention on the use of decay constants in geo-and cosmochronology. Earth and Planetary Science Letters 36, 359-362.

Szlabóczky, P., 1982. Jelentés a budakalászi mészkőbánya előzetes-részletes fázisú kutatásáról (Report about preliminary and detailed exploration of the Budakalász travertine). OFKFV 5, 47.

Teboul, P.-A., Durlet, C., Gaucher, E.C., Virgone, A., Girard, J.-P., Curie, J., Lopez, B. Camoin, G.F., 2016. Origins of elements building travertine and tufa: new perspectives provided by isotopic and geochemical tracers. Sedimentary Geology 334, 97-114.

Thirlwall, M.F., 1991. Long-term reproducibility of multicollector Sr and Nd isotope ratio analysis. Chemical Geology 94, 85-104.

Trunkó, L., 1996. Geology of Hungary. In: Beiträge zur Regionalen Geologie der Erde, 23. Borntraeger, Berlin, p. 464.

Tucker, M.E., Wright, V.P., 1990. Carbonate Sedimentology. Blackwell Publishing Ltd, Oxford, UK. http://dx.doi.org/10.1002/9781444314175.

Turi, B., 1986. Stable isotope geochemistry of travertines. In: Fritz, B.P., Fontes, J.C. (Eds.), Handbook of Environmental Isotope Geochemistry. Elsevier, Amsterdam, pp. 207-235.

Van Noten, K., Claes, H., Soete, J., Foubert, A., Özkul, M., Swennen, R., 2013. Fracture networks and strike-slip deformation along reactivated normal faults in Quaternary travertine deposits, Denizli Basin, Western Turkey. Tectonophysics 588 $154-170$.

Vanhaecke, F., Vanhoe, H., Dams, R., Vandecasteele, C., 1992. The use of internal standards in ICP-MS. Talanta 39, 131-142.

Vanhaecke, F., De Wannemacker, G., Moens, L., Hertogen, J., 1999. The determination of strontium isotope ratios by means of quadrupolebased ICP-mass spectrometry: a geochronological case study. Journal of Analytical Atomic Spectrometry $14,1691-1696$.

Violante, C., Ferreri, V., D'Argenio, B., Golubic, S., 1994. Quaternary travertines at Rochetta a Volturno (Isernia, Central Italy). Facies analysis and sedimentary model of an organogenic carbonate system. In: PreMeeting Fieldtrip Guidebook, A1, International Association of Sedimentologists, Ischia'94, 15th Regional Meeting, Italy, p. 3223.

Vitális, Gy, Hegyi, I., 1982. Adatok a Budapest térségi édesvízi mészkövek genetikájához (Data to genesis of travertine in Budapest and its surroundings) Hidrológiai Közlöny 2, 73-83 (In Hungarian).

Wein, Gy, 1977. A Budai-hegység tektonikája (Tectonism of the Buda Hills), p. 76. MÁFI Alkalmi kiadvány, (In Hungarian). 